\title{
Combination inhaled steroid and long-acting beta2-agonist versus tiotropium for chronic obstructive pulmonary disease (Review)
}

\author{
Welsh EJ, Cates CJ, Poole P
}

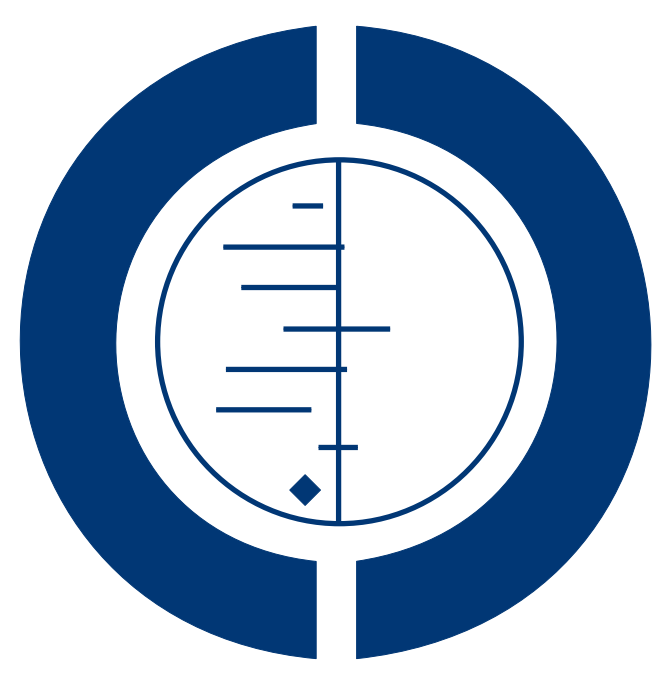

\section{THE COCHRANE COLLABORATION $^{\circledR}$}

This is a reprint of a Cochrane review, prepared and maintained by The Cochrane Collaboration and published in The Cochrane Library 2011, Issue 7

http://www.thecochranelibrary.com

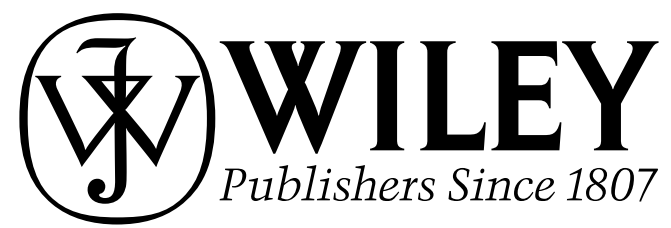

Combination inhaled steroid and long-acting beta2-agonist versus tiotropium for chronic obstructive pulmonary disease (Review) Copyright (@) 20II The Cochrane Collaboration. Published by John Wiley \& Sons, Ltd. 
TABLE OF CONTENTS

HEADER . . . . . . . . . . . . . . . . . . . . . . . . . . . . . . . . . . . . . . . 1

ABSTRACT . . . . . . . . . . . . . . . . . . . . . . . . . . . . . . . . . . . . . . . . . . . . 1

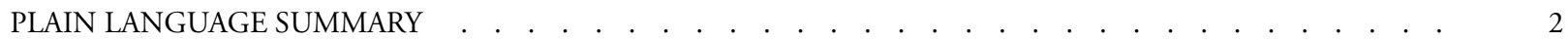

BACKGROUND . . . . . . . . . . . . . . . . . . . . . . . . . . . . . . . . . . . . 2

OBJECTIVES . . . . . . . . . . . . . . . . . . . . . . . . . . . . . . . . . . . . . 3

METHODS . . . . . . . . . . . . . . . . . . . . . . . . . . . . . . . . . . . . . . 3

RESULTS . . . . . . . . . . . . . . . . . . . . . . . . . . . . . . . . . . . . . . . 5

Figure 1. . . . . . . . . . . . . . . . . . . . . . . . . . . . . . . . . . . . . 6

DISCUSSION . . . . . . . . . . . . . . . . . . . . . . . . . . . . . . . . . . . . . 8

AUTHORS' CONCLUSIONS . . . . . . . . . . . . . . . . . . . . . . . . . . . . . . . . . . . . . . . . 10

ACKNOWLEDGEMENTS . . . . . . . . . . . . . . . . . . . . . . . . . . . . . . . . . . . . . . . . . .

REFERENCES . . . . . . . . . . . . . . . . . . . . . . . . . . . . . . . . . . . 10

CHARACTERISTICS OF STUDIES . . . . . . . . . . . . . . . . . . . . . . . . . . . . . 12

DATA AND ANALYSES . . . . . . . . . . . . . . . . . . . . . . . . . . . . . . . . . . . . . . . . . . . . . . . . . 19

Analysis 1.1. Comparison 1 Fluticasone/Salmeterol (FPS) versus Tiotropium (Tio), Outcome 1 Mortality (All-cause). 20

Analysis 1.2. Comparison 1 Fluticasone/Salmeterol (FPS) versus Tiotropium (Tio), Outcome 2 Hospital Admission. 20

Analysis 1.3. Comparison 1 Fluticasone/Salmeterol (FPS) versus Tiotropium (Tio), Outcome 3 Exacerbations (all cause): number of patients experiencing one or more exacerbations over two years. . . . . . . . . . . . . . . . . 21

Analysis 1.4. Comparison 1 Fluticasone/Salmeterol (FPS) versus Tiotropium (Tio), Outcome 4 Exacerbations (mean number of exacerbations per patient per year). . . . . . . . . . . . . . . . . . . . . . . 21

Analysis 1.5. Comparison 1 Fluticasone/Salmeterol (FPS) versus Tiotropium (Tio), Outcome 5 Pneumonia. . . . $\quad 22$

Analysis 1.6. Comparison 1 Fluticasone/Salmeterol (FPS) versus Tiotropium (Tio), Outcome 6 Quality of Life. . . $\quad 22$

Analysis 1.7. Comparison 1 Fluticasone/Salmeterol (FPS) versus Tiotropium (Tio), Outcome 7 FEV (Litres). $_{\text {. }}$. $\quad 23$

Analysis 1.8. Comparison 1 Fluticasone/Salmeterol (FPS) versus Tiotropium (Tio), Outcome 8 Serious Adverse Events (non-fatal). . . . . . . . . . . . . . . . . . . . . . . . . . . . . . . . . . . . 23

Analysis 1.9. Comparison 1 Fluticasone/Salmeterol (FPS) versus Tiotropium (Tio), Outcome 9 Adverse Events. . . $\quad 24$

Analysis 1.10. Comparison 1 Fluticasone/Salmeterol (FPS) versus Tiotropium (Tio), Outcome 10 Withdrawal. . . 24

ADDITIONAL TABLES . . . . . . . . . . . . . . . . . . . . . . . . . . . . . . . . . . . 25

APPENDICES . . . . . . . . . . . . . . . . . . . . . . . . . . . . . . . . . . . . . . 26

FEEDBACK . . . . . . . . . . . . . . . . . . . . . . . . . . . . . . . . . . . . . . 27

WHAT'S NEW . . . . . . . . . . . . . . . . . . . . . . . . . . . . . . . . . . . . 28

HISTORY . . . . . . . . . . . . . . . . . . . . . . . . . . . . . . . . . . . 28

CONTRIBUTIONS OF AUTHORS . . . . . . . . . . . . . . . . . . . . . . . . . . . . . . . . . . . . . . 28

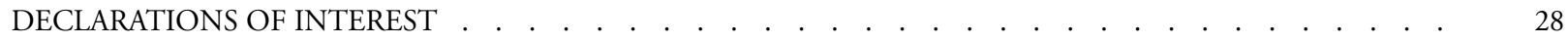

SOURCES OF SUPPORT . . . . . . . . . . . . . . . . . . . . . . . . . . . . . . . . . . . . . . . . . . . . 28

DIFFERENCES BETWEEN PROTOCOL AND REVIEW . . . . . . . . . . . . . . . . . . . . . . . . . . . . 29

INDEX TERMS . . . . . . . . . . . . . . . . . . . . . . . . . . . . . . . . . . . . . . . . . . . . . . 29

Combination inhaled steroid and long-acting beta2-agonist versus tiotropium for chronic obstructive pulmonary disease (Review)

Copyright ( 201 I The Cochrane Collaboration. Published by John Wiley \& Sons, Ltd. 


\title{
Combination inhaled steroid and long-acting beta2-agonist versus tiotropium for chronic obstructive pulmonary disease
}

\author{
Emma J Welsh ${ }^{1}$, Christopher J Cates ${ }^{1}$, Phillippa Poole ${ }^{2}$ \\ ${ }^{1}$ Population Health Sciences and Education, St George's, University of London, London, UK. ${ }^{2}$ Department of Medicine, University \\ of Auckland, Auckland, New Zealand
} Contact address: Emma J Welsh, Population Health Sciences and Education, St George’s, University of London, Cranmer Terrace,
London, SW17 0RE, UK. ewelsh@sgul.ac.uk.

Editorial group: Cochrane Airways Group.

Publication status and date: Edited (no change to conclusions), comment added to review, published in Issue 7, 2011.

Review content assessed as up-to-date: 7 October 2009.

Citation: Welsh EJ, Cates CJ, Poole P. Combination inhaled steroid and long-acting beta2-agonist versus tiotropium for chronic obstructive pulmonary disease. Cochrane Database of Systematic Reviews 2010, Issue 5. Art. No.: CD007891. DOI: 10.1002/14651858.CD007891.pub2.

Copyright (C) 2011 The Cochrane Collaboration. Published by John Wiley \& Sons, Ltd.

\begin{abstract}
A B S T R A C T
Background

Combination therapy (inhaled corticosteroids and long-acting beta 2 -agonists) and tiotropium are both used in the treatment of chronic obstructive pulmonary disease (COPD). There is uncertainty about the relative benefits and harms of these treatments.
\end{abstract}

Objectives

To assess the relative effects of inhaled combination therapy and tiotropium on patients with COPD.

\section{Search methods}

We searched the Cochrane Airways Group Specialised Register of trials (March 2010) and reference lists of articles. We also contacted authors of the studies.

\section{Selection criteria}

We included only parallel, randomised controlled trials comparing inhaled combination corticosteroid and long-acting beta2-agonist against inhaled tiotropium bromide.

Data collection and analysis

Two authors independently assessed trials for inclusion and then extracted data on trial quality and outcome results. We contacted study authors for additional information. Discrepancies were resolved through discussion.

Main results

One large two year trial (INSPIRE) and two smaller, shorter trials (Dawber 2005; SCO40034) were found. The results from these trials were not pooled. The number of withdrawals from each arm of the INSPIRE trial was large and imbalanced and outcome data was not collected for patients who withdrew, raising concerns about the reliability of data from this study.

In INSPIRE, there were more deaths on tiotropium than on fluticasone/salmeterol (Peto OR 0.55; 95\% CI 0.33 to 0.93). This was a statistically significant difference, however the number of withdrawals from each of the arms was eleven times larger than the observed 
number of deaths for participants on fluticasone/salmeterol and seven times larger for participants on tiotropium. There were more all cause hospital admissions in patents on fluticasone/salmeterol than those on tiotropium in INSPIRE (Peto OR 1.32; 95\% CI 1.04 to 1.67). There was no statistically significant difference in hospital admissions due to exacerbations, the primary outcome of INSPIRE. There was no significant difference in exacerbations in patients on fluticasone/salmeterol compared to tiotropium when compared as either an odds ratio or a rate ratio (mean number of exacerbations per patient per year). Exacerbations requiring treatment with oral corticosteroids were less frequent in patients on fluticasone/salmeterol (Rate Ratio 0.81; 95\% CI 0.67 to 0.99). Conversely exacerbations requiring treatment with antibiotics were more frequent in patients treated with fluticasone/salmeterol (Rate Ratio 1.19; 95\% CI 1.02 to 1.38). There were more cases of pneumonia in patients on fluticasone/salmeterol than those on tiotropium (Peto OR 2.13; $95 \%$ CI 1.33 to 3.40). Confidence intervals for these outcomes do not reflect the additional uncertainty arising from unknown outcome data for patients who withdrew.

\section{Authors' conclusions}

Since the proportion of missing outcome data compared to the observed outcome data is enough to induce a clinically relevant bias in the intervention effect, the relative efficacy and safety of combined inhalers and tiotropium remains uncertain. Further large, longterm randomised controlled trials comparing combination therapy to tiotropium are required, including adequate follow-up of all participants randomised (similar to the procedures undertaken in TORCH and UPLIFT). Additional studies comparing alternative inhaled LABA/steroid combination therapies with tiotropium are also required.

\section{PLAIN LANGUAGE SUMMARY}

\section{Combined inhalers compared to tiotropium inhalers for the treatment of chronic obstructive pulmonary disease}

Chronic Obstructive Pulmonary Disease (COPD) is a general term referring to chronic bronchitis and emphysema, or both. COPD occurs when airflow to the lungs is restricted. Symptoms include cough and breathlessness and inhalers are commonly used to prevent and relieve these symptoms. COPD is usually caused by smoking and the best way to improve symptoms is to give up smoking.

COPD trials lasting longer than six months often have large numbers of people leaving the trial early. In INSPIRE, the largest trial in our review comparing fluticasone/salmeterol to tiotropium, there were seven to eleven times more people leaving the trial early than the number who died; a number that swamps the death rate. Therefore we felt unable to draw a reliable conclusion as to which treatment has the lowest mortality rate. This uncertainty also left us unable to reliably say which drug was better in terms of reducing COPD exacerbations, hospitalisations, serious adverse events or improving quality of life and health status.

More information about COPD and explanations of terms used in this summary can be found here

\section{B A C K G R O U N D}

\section{Description of the condition}

Chronic obstructive pulmonary disease (COPD) is characterised by chronic airflow limitation, limited response to short-acting beta 2 -agonists, and is associated with a smoking history (GOLD). Symptoms of COPD include breathlessness and impaired exercise capacity. There are a number of commonly used pharmacological treatments in COPD management including inhaled shortacting beta-agonists (SABA), long-acting beta 2 -agonists (LABA) (Appleton 2006a), inhaled corticosteroids (ICS) (Yang 2007) and anticholinergics such as tiotropium (Barr 2005) and ipratropium bromide (Appleton 2006b; Appleton 2006c). Self-management education and pulmonary rehabilitation should accompany these pharmacological interventions (Effing 2007; Lacasse 2006).

\section{Description of the intervention}

Combination therapy is a maintenance inhaler that delivers an inhaled corticosteroid and a long-acting beta-agonist concurrently at the same dose. Combination therapy is currently available as combination fluticasone and salmeterol (marketed as Seretide or Advair, GSK) and budesonide and formoterol (marketed as Symbicort, AstraZeneca). Both combination products are licensed for 
use in COPD at the highest doses of ICS (daily dose fluticasone $1,000 \mu \mathrm{g}$ and budesonide $800 \mu \mathrm{g}$ ). Inhaled corticosteroids are anti-inflammatories and long-acting beta-agonists cause smooth muscle relaxation resulting in bronchodilation.

Tiotropium bromide (marketed as 'Spiriva', Boehringer Ingelheim) is an inhaled long-acting anticholinergic agent, and has gained widespread acceptance as a maintenance therapy in COPD (Barr 2005; GOLD; UPLIFT). Tiotriopium is a long-acting anticholinergic agent that targets bronchospasm in COPD by relaxing airway smooth muscle.

\section{Why it is important to do this review}

Both tiotropium and combination inhalers have been shown to improve key clinical indicators of disease in clinical trials against placebo.

Combination therapy has been shown to reduce exacerbations, mortality and to improve health status compared to placebo (Nannini 2007a). Inhaled corticosteroids alone have been shown to reduce COPD exacerbations (Yang 2007). Long-acting betaagonists have also been shown to reduce exacerbations and improve lung function (Appleton 2006a). The effects of combination treatment against component monotherapy are more variable (Nannini 2007b; Nannini 2007c). However, concerns have been raised about the risk of pneumonia associated with ICS in COPD patients (Singh 2009).

Benefits of tiotropium in comparison with placebo include reduced exacerbations and related hospital admissions, and improvements in quality of life and lung function (Barr 2005; UPLIFT). However, in the UPLIFT trial conducted over four years tiotropium did not slow the rate of decline in $\mathrm{FEV}_{1}$ compared with placebo (UPLIFT). Concerns that inhaled anticholinergics increase the long-term risk of major cardiovascular events in COPD have been raised (Singh 2008b), but this was not found in UPLIFT.

This leaves clinicians and patients facing uncertainty as to the relative merits of these treatments, and how the side-effect profiles of each compare.

\section{O B J E C T I VES}

To compare the relative effects of inhaled combination therapy and tiotropium on markers of exacerbations, symptoms, quality of life, lung function, pneumonia and serious adverse events in patients with chronic obstructive pulmonary disease.

\section{METHODS}

\section{Criteria for considering studies for this review}

\section{Types of studies}

We included only randomised controlled trials with a parallel group design comparing the interventions. Studies were not excluded on the basis of blinding.

\section{Types of participants}

Populations with a diagnosis of chronic obstructive pulmonary disease. We only included studies where an external set of criteria had been used to screen participants for this condition (e.g. GOLD, ATS, BTS, TSANZ).

\section{Types of interventions}

1. Inhaled combination corticosteroid and long-acting beta 2 agonist (such as fluticasone/salmeterol, budesonide/formoterol, beclomethasone/formoterol).

2. Inhaled tiotropium bromide

\section{Types of outcome measures}

\section{Primary outcomes}

1. Mortality (all cause)

2. Hospital admission

3. Exacerbations; all cause, requiring short courses of oral corticosteroids or antibiotics as defined by agreed criteria

4. Pneumonia

\section{Secondary outcomes}

1. Quality of life (measured with a validated scale for COPD, e.g. St George's Respiratory Questionnaire, Chronic Respiratory Disease Questionnaire)

2. Symptoms

3. Forced expiratory volume in one second $\left(\mathrm{FEV}_{1}\right)$

4. Non-fatal serious adverse events

5. Adverse events

6. Withdrawals

\section{Search methods for identification of studies}

\section{Electronic searches}

We identified trials using the Cochrane Airways Group Specialised Register of trials, which is derived from systematic searches of 
bibliographic databases including the Cochrane Central Register of Controlled Trials (CENTRAL), MEDLINE, EMBASE, CINAHL, AMED, and PsycINFO, and handsearching of respiratory journals and meeting abstracts (see the Airways Group Module for further details). All records in the Specialised Register coded as 'COPD' were searched using the following terms:

(tiotropium or spiriva) AND (((budesonide or fluticasone or beclomethasone or mometasone or steroid* or corticosteroid*) and (formoterol or salmeterol or indacterol or (beta* and agonist*))) or (symbicort or viani or seretide or advair or foster or fostair or inuvair or combination*))

The search was conducted in March 2010.

\section{Searching other resources}

We reviewed reference lists of all primary studies and review articles for additional references. We contacted authors of identified trials and manufacturers to ask if they knew of other published or unpublished studies.

\section{Data collection and analysis}

\section{Selection of studies}

Two review authors (EJW and CJC) screened the titles and abstracts of citations retrieved through literature searches and obtained full papers of references deemed to be potentially relevant. We assigned each reference to a study identifier and assessed them against the inclusion criteria of the review.

\section{Data extraction and management}

We extracted characteristics and data for studies that met the eligibility criteria of the review using a dedicated extraction sheet. The extraction of characteristics and data was performed in duplicate, and discrepancies were identified and resolved through discussion.

\section{Assessment of risk of bias in included studies}

We assessed the risk of bias according to recommendations outlined in Cochrane Handbook for the following items:

1. Allocation sequence generation

2. Concealment of allocation

3. Blinding of participants and investigators

4. Handling of missing data

Each potential source of bias was graded as yes, no or unclear, relating to whether the potential for bias was low, high or unknown respectively.

\section{Measures of treatment effect}

We intended to combine dichotomous data variables (such as mortality, pneumonia and study withdrawal) as Peto Odds Ratios (OR) with $95 \%$ confidence intervals as this is more suitable than Maentel-Haenszel for rare events. However, the events in INSPIRE were not rare. We cross-checked all the Peto Odds Ratios with the Maentel-Haenszel Odds Ratios and found no difference, so we reported the Peto Odds Ratio as per protocol. We planned to combine continuous outcome data (such as symptoms, quality of life and $\mathrm{FEV}_{1}$ ) as fixed effect mean differences with $95 \%$ confidence intervals. In INSPIRE, exacerbations were reported as rate ratios (RR), and we entered these data into RevMan 5.0 using the GIV function.

\section{Unit of analysis issues}

Data on exacerbations were provided by INSPIRE trialists as the difference in exacerbation rates between patients on fluticasone/ salmeterol and those on tiotropium, and were based on rate ratios using negative binomial model estimates and 95\% confidence intervals. The natural $\log$ of the rate ratio along with the standard error calculated from the confidence interval were entered into RevMan 5.0 using the GIV function and the resulting confidence intervals were cross-checked with those provided by INSPIRE for exacerbations.

Data for quality of life and $\mathrm{FEV}_{1}$ were calculated as a mean difference with $95 \%$ confidence intervals. We entered the mean difference and standard errors calculated from $95 \%$ confidence intervals into RevMan 5.0 and analysed it using the GIV tool in RevMan 5.0.

\section{Dealing with missing data}

We contacted investigators or study sponsors in order to verify key study characteristics and to obtain missing numerical data.

\section{Assessment of heterogeneity}

We planned to assess the amount of statistical variation between the study results with the $\mathrm{I}^{2}$ measurement.

\section{Data synthesis}

We planned to calculate numbers needed to treat from the pooled Odds Ratio and its confidence interval, and apply them to appropriate levels of baseline risk.

We intended to present the findings of our four primary outcomes (mortality, hospital admission, exacerbations and pneumonia) in a summary of findings table generated using GradePro software. 


\section{Subgroup analysis and investigation of heterogeneity}

We planned to subgroup studies according to:

1. Type and dose of combination therapy

2. Severity of disease at baseline

\section{Sensitivity analysis}

We intended to assess the sensitivity of our primary outcomes to degree of bias. We planned to compare the Peto Odds Ratio results for dichotomous outcomes with Mantel-Haenszel fixed and random models and with the pooled risk differences.

\section{R E S U L T S}

\section{Description of studies}

See: Characteristics of included studies; Characteristics of excluded studies.

See Characteristics of included studies and Characteristics of excluded studies.

\section{Results of the search}

The initial search was carried out in October 2009 and identified 81 references. Of these 13 were potentially relevant and were obtained in full text for further assessment. Eight of these full text documents were eligible and belonged to three included studies (Dawber 2005; INSPIRE; SCO40034). A further report on Dawber 2005 was identified from the GlaxoSmithKline (GSK) trial register. We asked five trialists if they knew of any other published and unpublished trials; there were five responses but no relevant studies that had not already been located by the search were identified. Eight further references were returned by an updated search in March 2010, but none of these was eligible.

\section{Included studies}

\section{Participants}

A total of 1507 participants were recruited into the three eligible studies (Dawber 2005; INSPIRE; SCO40034). INSPIRE was by far the largest included trial, with 1,323 participants, whilst Dawber 2005 had 59 and SCO 40034 had 125 participants. INSPIRE was a two year trial whilst Dawber 2005 and SCO 40034 were much shorter at three and twelve weeks respectively. Owing to the disparity in the trial lengths and because the primary focus of our review was on long-term outcomes, we did not pool the results of the trials. This review therefore focusses primarily on the results of INSPIRE.
Patients in INSPIRE were classified as having GOLD stage III ( $\mathrm{FEV}_{1} \geq 30$ to $<50 \%$ predicted) or GOLD stage IV ( $\mathrm{FEV}_{1}<30 \%$ predicted). There were $\mathrm{N}=540$ patients with stage III COPD on fluticasone/salmeterol with a mean $\mathrm{FEV}_{1}$ of $1.09 \mathrm{~L}$ and $\mathrm{N}=537$ patients with a mean $\mathrm{FEV}_{1}$ of $1.11 \mathrm{~L}$ on tiotropium. There were $\mathrm{N}=100$ patients with stage IV COPD on fluticasone/salmeterol with a mean $\mathrm{FEV}_{1}$ of $0.73 \mathrm{~L}$ and $\mathrm{N}=101$ patient with a mean $\mathrm{FEV}_{1}$ of $0.71 \mathrm{~L}$ on tiotropium. In INSPIRE, $48 \%$ of participants in the fluticasone/salmeterol arm and $51 \%$ in the tiotropium arm stopped taking inhaled corticosteroids at baseline. All participants had a smoking history of greater than 10 pack years.

\section{Interventions}

Patients recruited to INSPIRE received either fluticasone/salmeterol $(500 / 50 \mu \mathrm{g}$ twice a day) as a dry powder via a DISKUS or Accuhaler inhaler or tiotropium (18 $\mu \mathrm{g}$ once a day) delivered via a dry-powder Handihaler.

Participants in INSPIRE were allowed to take short-acting beta 2 -agonists and short courses of oral corticosteroids alongside their study medications. Prior to randomisation, participants in INSPIRE were given oral prednisolone $(30 \mathrm{mg})$ once a day and inhaled fluticasone/salmeterol $(500 / 50 \mu \mathrm{g})$ twice a day during a two week run-in period.

\section{Outcomes}

The primary outcomes varied between the studies and were different from our primary outcomes. The primary outcome for INSPIRE was the rate of health care utilisation for COPD exacerbations, which we incorporated in to our review. The primary outcome assessed by Dawber 2005 was mucociliary clearance rate expressed as the percent particle retention at 2.5 hours. SCO40034 was an exploratory study to compare the clinical efficacy of fluticasone/salmeterol against tiotropium and therefore did not define a primary outcome.

\section{Excluded studies}

A total of four studies failed to meet the eligibility criteria for the review (see Characteristics of excluded studies). Three trials (Golabi 2006; Hara 2007; Singh 2008) were excluded because they were crossover trials, which are not suitable for assessing longterm outcomes.

One trial (Bateman 2008) was excluded because the intervention compared fluticasone $(250 \mu \mathrm{g})$ and salmeterol $(50 \mu \mathrm{g})$ administered via separate metered dose inhalers to tiotropium $(18 \mu \mathrm{g})$. We felt that this could lead to discrepancies in the analysis if participants stopped taking one inhaler and continued taking the other. This randomised, double-blind, triple-dummy pilot study administered fluticasone and salmeterol to 51 participants and tiotropium to 56 participants. The participants had moderate or severe COPD and a smoking history of greater than 10 pack years 
although the baseline characteristics were not comparable across both arms. The primary outcome was $\mathrm{FEV}_{1}$ and there was no significant difference in the lung function or occurrence of adverse effects between the two intervention arms after 43 days and there was a single dropout in the fluticasone/salmeterol arm.

\section{Risk of bias in included studies}

An assessment of the risk of bias is presented in the Characteristics of included studies table and summarised in a risk of bias table (Figure 1)

Figure I. Methodological quality summary: review authors' judgements about each methodological quality item for each included study.

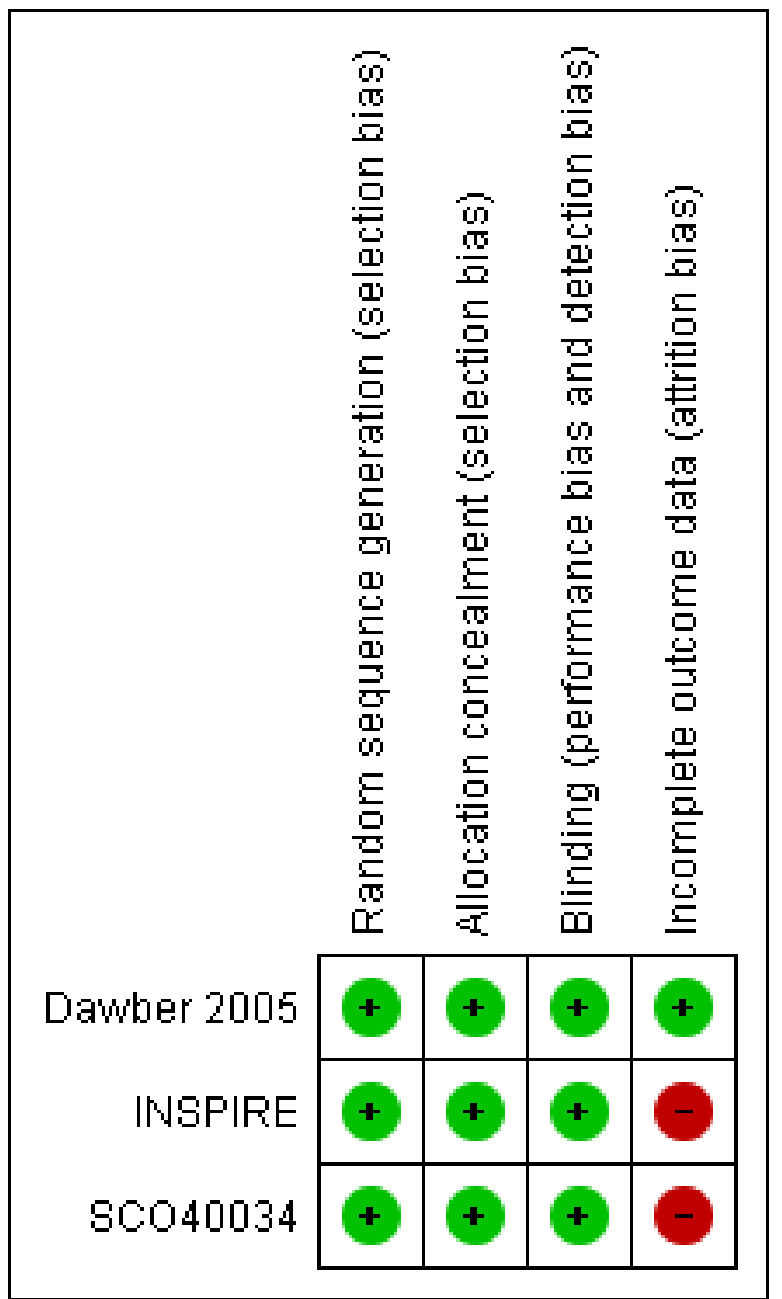




\section{Allocation}

INSPIRE reported adequate sequence generation and allocation concealment. Dawber 2005 and SCO40034 did not report full details in the study reports, but GSK supplied unpublished information describing adequate computerised randomisation and allocation on request.

\section{Blinding}

All three trials were blinded by employing a double-dummy design; the two drugs were administered via different types of inhaler, each participant was given two inhalers to use each day, one containing the intervention medication and a second containing placebo. Neither the patient nor the investigator knew what medication a particular participant was randomised to.

\section{Incomplete outcome data}

INSPIRE suffered from high withdrawal rates, and data were not collected for patients who withdrew. For a discussion of the methodological issues affecting COPD trials see Discussion.

\section{Selective reporting}

All three trials adequately reported outcome data for the primary and secondary outcomes that they had pre-specified in the study record.

\section{Effects of interventions}

\section{Primary outcome: Mortality (all cause)}

In INSPIRE, there were more deaths on tiotropium (38/665 people) than on fluticasone/salmeterol (21/658) (Peto OR 0.55; 95\% CI 0.33 to 0.93 ). Although this was a statistically significant difference, the number of withdrawals from each of the arms was eleven times larger than the number of deaths for participants on fluticasone/salmeterol and seven times larger for participants on tiotropium. This uncertainty about the results is not reflected in the confidence interval for the odds ratio.

\section{Primary outcome: Hospital admission}

There were more all cause hospital admissions in patents on fluticasone/salmeterol (215/658) than those on tiotropium (179/665) in INSPIRE (Peto OR 1.32; 95\% CI 1.04 to 1.67 ). The primary outcome of INSPIRE was hospital admissions due to exacerbations. More patients on salmeterol/fluticasone were hospitalised due to exacerbations $(105 / 658)$ compared to tiotropium $(86 / 665)$ (Peto OR 1.28; 95\% CI 0.94 to 1.74 ), but this was not statistically significant.

\section{Primary outcome: Exacerbations}

Data for all cause exacerbations was reported as both count data and as a rate (i.e. the mean number of exacerbations per year) in INSPIRE. The differences between these methods of analysis are discussed in the Summary of main results.

Firstly, looking at the number of people experiencing one or more exacerbations. There was no significant difference in the number of people experiencing one or more exacerbations, (408/658 in the fluticasone/salmeterol arm versus 393/665 in the tiotropium arm; Analysis 1.3).

The number of exacerbations was also reported as the mean number of events per year. There was no significant difference in exacerbations of any type in patients on fluticasone/salmeterol compared to tiotropium (RR 0.97; 95\% CI 0.84 to 1.12; Analysis 1.4). Overall $62 \%$ of the fluticasone/salmeterol group and $59 \%$ of the tiotropium group had one or more exacerbation requiring therapeutic intervention and the trialists estimated this to equate to 1.28 and 1.32 exacerbation per year for patients on fluticasone/ salmeterol and tiotropium respectively. Exacerbations requiring treatment with oral corticosteroids were more frequent in patients on tiotropium (RR $0.81 ; 95 \%$ CI 0.67 to 0.99 ) and conversely exacerbations requiring treatment with antibiotics were more frequent in patients treated with fluticasone/salmeterol (RR 1.19; 95\% CI 1.02 to 1.38$)$.

\section{Primary outcome: Pneumonia}

There were more cases of pneumonia in patients on fluticasone/ salmeterol (50/658) than in those on tiotropium (24/665) (Peto OR 2.13; $95 \%$ CI 1.33 to 3.40). There were several figures reported for pneumonia in the INSPIRE trial (see Table 1) all of which indicated that there were more cases of pneumonia in participants on fluticasone/salmeterol compared to those on tiotropium. While this is statistically significant, there is considerable uncertainty over the clinical interpretation of this result owing to the large drop out rates. Moreover, if this is a true finding, the higher pneumonia rate in the combination group was not associated with a significant increase in exacerbations, hospitalisations due to exacerbations or deaths.

\section{Secondary outcome: Quality of life}

Patients on fluticasone/salmeterol reported better quality of life than those on tiotropium at two years from baseline (MD -2.07; $95 \%$ CI -4.02 to -0.12 ). In real terms, this meant that patients on salmeterol/fluticasone reported a mean improvement in quality of life of 1.7 units on the St. Georges Respiratory Questionnaire (SGRQ) whilst those on tiotropium reported a mean worsening in their quality of life of 0.4 units. The minimum clinically important difference in quality of life measured on the SGRQ is four units. INSPIRE reported that $35 \%$ of patients on fluticasone/salmeterol and $27 \%$ patients on tiotropium (OR $1.29 ; 95 \%$ CI 1.04 to 1.60 ) 
experienced an improvement in quality of life of $\geq$ four units. Data for the number of patients who had a deterioration in quality of life of $\geq$ four units was not reported (Jones 2009).

\section{Secondary outcome: Forced expiratory volume in one second $\left(\right.$ FEV $\left._{1}\right)$}

$\mathrm{FEV}_{1}$ data were available at a number of time points in INSPIRE and therefore data were entered at both eight weeks and two years. At eight weeks, $\mathrm{FEV}_{1}$ had increased by $0.04 \mathrm{~L}( \pm 0.010)$ from baseline in patients on fluticasone/salmeterol, whilst those on tiotropium had an increase of $0.06 \mathrm{~L}( \pm 0.010)$. There was no statistically significant between group difference (MD -0.02; $95 \%$ CI -0.05 to 0.01$)$. At two years, the $\mathrm{FEV}_{1}$ of patients on fluticasone/salmeterol had decreased by $-0.01 \mathrm{~L}( \pm 0.012)$ compared to baseline whilst those on tiotropium showed an improvement compared to baseline of $\mathrm{FEV}_{1} 0.01 \mathrm{~L}( \pm 0.013)$, again not a statistically significant between group difference (MD -0.02; 95\% CI -0.05 to 0.01$)$.

\section{Secondary outcome: Serious adverse events (Non-fatal)}

There were more serious adverse events in patients on fluticasone/ salmeterol $(194 / 658)$ than in patients on tiotropium (141/665) (Peto OR 1.55; 95\% CI 1.21 to 1.98 ) in INSPIRE.

\section{Secondary outcome: Adverse events}

In INSPIRE there were fewer adverse events among patients on fluticasone/salmeterol (435/658) than tiotropium (414/665) (Peto OR 1.18 ; $95 \%$ CI 0.94 to 1.48 ).

\section{Secondary outcome: Withdrawal}

There were large numbers of withdrawals from INSPIRE and the withdrawal rate was higher in the tiotropium group than in the fluticasone/salmeterol group. There were fewer withdrawals for any reason for patients on fluticasone/salmeterol (232/658, 35\%) compared with tiotropium $(279 / 665,42 \%$ ) (Peto OR 0.75; $95 \%$ CI 0.60 to 0.94$)$. The difference between the number withdrawing due to adverse events (Peto OR 1.03; 95\% CI 0.72 to 1.47 ) and lack of efficacy (Peto OR 0.84; 95\% CI 0.52 to 1.37) was not statistically significant. The INSPIRE trialists reported reasons for withdrawal (Table 2) and this demonstrated that the greatest difference was higher rates of withdrawal due to COPD exacerbations in patients on tiotropium than in those on fluticasone/ salmeterol.

There were no data reported for symptoms.

\section{Summary of results for Dawber 2005 and SC040034}

There were no deaths in either Dawber 2005 or SCO40034. There was no significant difference in hospital admissions, cases of pneu- monia, $\mathrm{FEV}_{1}$, serious adverse events or adverse events in either Dawber 2005 or SCO40034. There were more withdrawals in patients on tiotropium compared to fluticasone/salmeterol in patients in the SCO40034 trial.

\section{DISCUSSION}

\section{Methodological issues in COPD trials}

Withdrawal rates in COPD trials are commonly high, especially in studies longer than six months in duration. There is no consensus on how to handle participants for whom data is not available ( Cochrane Handbook). There are two available options: intentionto-treat analysis, or available case analysis.

The principles of intention-to-treat analyses are that participants are analysed according to the intervention group to which they were initially randomised regardless of the treatment received. Outcome data are recorded for all participants, and all randomised participants are included in the analysis. Performing analyses on a true intention-to-treat basis when outcome data for all participants is missing is not possible. To perform an intention-to-treat analysis regardless of the missing data does not take into account participants who withdraw and gives an overly precise estimate of the treatment effect. When withdrawals are related to the treatment (i.e. not at random), the participants who withdraw are likely to have poorer outcomes than those who remain in the trial and provide data (Suissa 2008). This can lead to a 'healthy survivor' effect.

One way to deal with missing outcome data due to withdrawals is imputation, and there are three ways of estimating missing values. One approach is to assume that the rate of events in the participants who withdraw occurs at the same rate as it does in those who remained in the study and provide data. This increases the precision of the estimate of the confidence intervals, but if the assumed rate of events is incorrect, the effect estimate for the study will be biased. A second option is to simulate best-case worst-case scenarios, where it is assumed that all the participants who withdrew on one intervention arm experienced the event and then repeat the analysis with the other intervention arm, comparing the results as a sensitivity analysis. This is problematic when the number of dropouts is significantly greater than the numbers of patients experiencing the event in the study. The third way is to assume that the rates of events in the withdrawals is similar to those observed in other similar trials.

However, full follow-up of patients that withdraw can introduce a different bias. Patients that withdraw are likely to begin treatment with another medication, but their outcomes are still attributed to the treatment group to which they were randomised. This is particularly problematic in head-to-head studies because patients 
often go onto the other study medication, which could potentially provide an inaccurate estimate of the true difference between the treatments.

Availiable case analysis, where treatment effect is based on the number of participants who provided data, does not take into account the outcomes of those who withdrew.

COPD patients who withdraw early tend to be sicker at recruitment and deteriorate faster than those who remain in the study. Additionally, because COPD is a chronic condition, many patients are already taking medication when they start a clinical trial and withdrawal symptoms can occur (Suissa 2008). In effect a trial can be looking at the effect of withdrawing an existing treatment as well as introducing a new one.

Participants in COPD trials are usually already taking medication for their condition before entry. Run-in periods, where participants take a standard treatment for a few weeks prior to randomisation were designed to account for the improvement in health status that comes at the start of a trial due to increased medical attention (Calverley 2003). However, these run-in periods limit the overall applicability of the results if the outcomes were affected by the run-in drugs, but attributed to the study medication (Suissa 2008a).

\section{Summary of main results}

The number of withdrawals from both arms of the INSPIRE trial was large and outcome data were not collected for patients who withdrew. It is feasible to record mortality data (vital status) for participants who withdrew, but not reasonably possible to obtain data for other outcomes. Because outcome data for those who withdrew were not available, the confidence intervals for the outcomes do not reflect this additional uncertainty. We cannot be sure that the mortality rate for patients who withdrew on either drug was higher, lower or the same as those who completed the study. It would be, in our opinion, inappropriate to apply simple imputation of data in this instance.

When patients withdraw from a study for reasons relating to outcomes, the perceived benefit (or lack thereof) of a study drug can have great influence over their decision to remain in the trial (Kesten 2007). Kesten 2007 reported higher incidence rates of death following premature discontinuation of study medication. INSPIRE trialists cited the differential withdrawal rate as an indirect marker of treatment efficacy. There was no significant difference in the withdrawals due to lack of efficacy or adverse events in INSPIRE although more people on tiotropium withdrew compared to those on fluticasone/salmeterol overall. The proportion of missing outcome data compared to the observed outcome data is enough to induce a clinically relevant bias in the intervention effect.

We presented exacerbations using two different units of analysis in this review. There are several ways to analyse exacerbation rates and each is associated with advantages or disadvantages (Keene
2008). Looking at the number of patients experiencing one or more exacerbations does not give any information about exacerbation frequency in the same patent and does not take into account duration of study (Keene 2008; Karner 2011). You therefore get different information from the number of people experiencing one or more exacerbations and the mean number of exacerbations per year. While neither of the methods of reporting all cause exacerbations resulted in a statistically significant difference, it is interesting to note that the direction of the treatment effect is different. Reported as number of people experiencing one or more exacerbations, there are fewer exacerbations in people on tiotropium. However looking at the relative rate, there are fewer exacerbations per year in patients on fluticasone/salmeterol. This may represent the play of chance, but we cannot rule out the possibility that the two treatments have different impacts on patients with occasional or frequent exacerbations.

\section{Quality of the evidence}

All three trials had adequate sequence generation, allocation concealment and blinding. Additionally, data was provided for the outcomes outlined in the protocols of the trials. The principal concern with the largest study addressing the review question, INSPIRE, relates to the handling of data from participants who withdrew.

\section{Potential biases in the review process}

We minimised bias in our search process thorough using comprehensive search terms and asking authors to identify other published an non-published studies. Studies were determined as included or excluded, data was extracted and risk of bias attributed in duplicate to minimise error.

\section{Agreements and disagreements with other studies or reviews}

Previous systematic reviews evaluating combined inhalers compared to placebo (Nannini 2007a) and combined inhalers compared to long-acting beta 2 -agonists (Nannini 2007b) have shown an elevated risk of pneumonia with combination therapy, (seeTable 3). There were relatively more cases of pneumonia reported in these systematic reviews (which included TORCH) and TORCH than were recorded in INSPIRE.

There were relatively fewer deaths in INSPIRE compared to TORCH that included complete follow up of vital status for participants who withdrew; $1.6 \%$ per year in INSPIRE compared to $4.2 \%$ per year in TORCH. There may have been at least as many deaths in patients who withdrew from INSPIRE as in those who completed the trial.

\section{Indirect comparison}


There are two Cochrane reviews that may serve as a useful indirect comparison of treatment efficacy; combination inhaled steroids and long-acting beta-agonists versus placebo (Nannini 2007a) and tiotropium versus placebo (Barr 2005). We include the following descriptions for comparison only and have not calculated an estimate of relative benefits and harms from these meta-analyses. Nannini 2007a reported outcomes for a total of 6427 participants in 11 studies. Two studies compared budesonide/formoterol, while the remaining studies compared fluticasone/salmeterol albeit at different doses. The meta-analysis was dominated by the largest trial TORCH which had complete follow up for vital status of all participants. All cause mortality was reduced in patients on combined inhalers compared to placebo (OR 0.79 (95\% CI 0.65 to $0.96)$ ). Exacerbations were less frequent in participants on combined inhalers (rate ratio 0.74 ( $95 \% \mathrm{CI} 0.7$ to 0.8$)$ ) and an increase in the risk of pneumonia was noted in the groups that received inhaled steroids either alone or in combination.

Barr 2005 reported outcomes for a total of 6584 participants across nine studies, comparing tiotropium to placebo, ipratropium or long-acting beta ${ }_{2}$-agonist. All cause mortality was reduced in participants on tiotropium compared to placebo (OR 0.73 (95\% CI 0.35 to 1.49 ) and COPD exacerbations were also reduced (OR 0.75 (95\% CI 0.66 to 0.85$)$ ). The only adverse event data available to pool was for dry mouth which was more frequently experienced by patients randomised to tiotropium than placebo.

\section{A U THORS' CONCLUSIONS}

\section{Implications for practice}

INSPIRE had a high and unbalanced withdrawal rate. The proportion of missing outcome data compared to the observed outcome data is enough to induce a clinically relevant bias in the intervention effect. The relative efficacy and safety of combined inhalers and tiotropium remains uncertain.

\section{Implications for research}

Further large, long-term randomised controlled trials comparing combination therapy to tiotropium are required including followup of all participants randomised (similar to TORCH and UPLIFT). Additional studies comparing alternative inhaled LABA/ steroid combination therapies with tiotropium are also required.

\section{ACKNOWLEDGEMENTS}

We are grateful to Liz Arnold for support in designing the search strategy.

\section{RE FER E N C E S}

\section{References to studies included in this review}

\section{Dawber 2005 \{published data only\}}

Dawber F, Tandy D, Haussermann S, Betz R. Efficacy of fluticasone/salmeterol propionate $50 / 500 \mathrm{mcg}$ bd versus tiotropium on lung function and mucociliary clearance in COPD patients [Abstract]. Respirology 2005; Vol. 10, issue Suppl 3:A99.

* GSK (SCO4011). A single centre, randomised, doubleblind, double dummy, parallel group 3-week study to compare the effect of the fluticasone/salmeterol propionate combination $50 / 500 \mathrm{mcg}$ bd via the DISKUSTM/ ACCUHALERTM inhaler with tiotropium bromide $18 \mathrm{mcg}$ od via the Handihaler inhaler on mucociliary clearance rate in patients with Chronic Obstructive Pulmonary Disease (COPD). http://www.gsk-clinicalstudyregister.com/files/ pdf/23676.pdf Acessed July 3rd 2009.

INSPIRE \{published data only\}

Calverley P, Stockley R, Seemungal T, Hagan G, Wedzicha $\mathrm{J}$. Adverse events and mortality in the INSPIRE study (investigating new standards for prophylaxis in reduction of exacerbations) [Abstract]. European Respiratory Journal 2007; Vol. 30, issue Suppl 51:125s [P847].

GSK (SCO40036). Multicentre, Randomised, DoubleBlind, Double Dummy, Parallel Group, 104-week Study to Compare the Effect of the Salmeterol/Fluticasone Propionate Combination Product (SERETIDE*) 50/ $500 \mathrm{mcg}$ Delivered Twice Daily via the DISKUS*/ ACCUHALER* Inhaler with Tiotropium Bromide 18 mcg Delivered Once Daily via the HandiHaler Inhalation Device on the Rate of Health Care Utilisation Exacerbations in Subjects with Severe Chronic Obstructive Pulmonary Disease (COPD). www.gsk-clinicalstudyregister.com/files/ pdf/21085.pdf Accessed June 16th 2009.

Seemungal T, Stockley R, Calverley P, Hagan G, Wedzicha $\mathrm{J}$. Effect of fluticasone/salmeterol propionate versus tiotropium bromide on exacerbations: the INSPIRE study (investigating new standards for prophylaxis in reduction of exacerbations) [Abstract]. European Respiratory Journal 2007; Vol. 30, issue Suppl 51:688s [E4055].

Seemungal T, Stockley R, Calverley P, Hagan G, Wedzicha JA. Investigating new standards for prophylaxis in reduction of exacerbations - The INSPIRE study methodology. COPD: Journal of Chronic Obstructive Pulmonary Disease 2007; Vol. 4, issue 3:177-83.

Stockley R, Calverley P, Seemungal T, Hagan G, Wedzicha J. Effect of fluticasone/salmeterol propionate versus tiotropium bromide on withdrawal rate, health status, lung function and mortality INSPIRE (investigating new 
standards for prophylaxis in reduction of exacerbations study) [Abstract]. European Respiratory Journal 2007; Vol. 30, issue Suppl 51:34s [388].

Wedzicha J, Stockley R, Seemungal T, Hagan G, Calverley P. The INSPIRE study: effect of fluticasone/salmeterol propionate versus tiotropium bromide on COPD exacerbations [Abstract]. Respirology 2007; Vol. 12, issue Suppl 4:A112.

* Wedzicha JA, Calverley PM, Seemungal TA, Hagan G, Ansari Z, Stockley RA, et al.The prevention of chronic obstructive pulmonary disease exacerbations by fluticasone/ salmeterol propionate or tiotropium bromide. American Journal of Respiratory \& Critical Care Medicine 2008; Vol. 177 , issue $1: 19-26$

\section{SCO40034 \{unpublished data only\}}

* GSK (SCO40034). A multicentre, randomised, doubleblind, double dummy, parallel group 12-week exploratory study to compare the effect of the fluticasone/salmeterol propionate combination product (SERETIDETM) 50/ $500 \mathrm{mcg}$ bd via the DISKUSTM/ACCUHALER ${ }^{\mathrm{TM}}$ inhaler with tiotropium bromide $18 \mathrm{mcg}$ od via the Handihaler inhalation device on efficacy and safety in patients with Chronic Obstructive Pulmonary Disease (COPD). www.gsk-clinicalstudyregister.com/files/pdf/23678.pdf Accessed June 16th 2009.

\section{References to studies excluded from this review}

\section{Bateman 2008 \{published data only\}}

Bateman ED, van Dyk M, Sagriotis A. Comparable spirometric efficacy of tiotropium compared with salmeterol plus fluticasone in patients with COPD: a pilot study. Pulmonary Pharmacology and Therapeutics 2008;21(1): 20-5.

Golabi 2006 \{published data only\} Golabi P, Topaloglu N, Karakurt S, Celikel T. Effects of tiotropium and fluticasone/salmeterol combination on lung hyperinflation dyspnea and exercise tolerance in COPD [Abstract]. European Respiratory Journal 2006; Vol. 28, issue Suppl 50:33s [E304].

\section{Hara 2007 \{published data only\}}

Hara K, Kurashima K, Tokunaga D, Ueno M, Aoyagi $\mathrm{K}$, Isobe $\mathrm{Z}$, et al.Single blind comparison of tiotropium and salmeterol plus fluticasone propionate of treatment in patients with chronic obstructive pulmonary disease (COPD) [Abstract]. American Thoracic Society International Conference, May 18-23, 2007, San Francisco, California, USA 2007:Poster \#A1.

\section{Singh 2008 \{published data only\}}

Singh D, Brooks J, Hagan G, Cahn A, O’Connor BJ. Superiority of "triple" therapy with fluticasone/salmeterol propionate and tiotropium bromide versus individual components in moderate to severe COPD. Thorax 2008; Vol. 63, issue 7:592-8.

\section{Additional references}

\section{Appleton 2006a}

Appleton S, Poole P, Smith B, Veale A, Lasserson TJ, Chan MMK, et al.Long-acting beta2-agonists for poorly reversible chronic obstructive pulmonary disease. Cochrane Database of Systematic Reviews 2006, Issue 3. [DOI: 10.1002/ 14651858.CD001104.pub2]

\section{Appleton 2006b}

Appleton S, Jones T, Poole P, Pilotto L, Adams R, Lasserson $\mathrm{TJ}$, et al.Ipratropium bromide versus short acting beta- 2 agonists for stable chronic obstructive pulmonary disease. Cochrane Database of Systematic Reviews 2006, Issue 2. [DOI: 10.1002/14651858.CD001387.pub2]

\section{Appleton 2006c}

Appleton S, Jones T, Poole P, Lasserson TJ, Adams R, Smith $\mathrm{B}$, et al.Ipratropium bromide versus long-acting beta- 2 agonists for stable chronic obstructive pulmonary disease. Cochrane Database of Systematic Reviews 2006, Issue 3. [DOI: 10.1002/14651858.CD006101]

\section{Barr 2005}

Barr RG, Bourbeau J, Camargo CA. Tiotropium for stable chronic obstructive pulmonary disease. Cochrane Database of Systematic Reviews 2005, Issue 2. [DOI: 10.1002/ 14651858.CD002876.pub2]

\section{Calverley 2003}

Calverley P M, Boonsawat W, Cseke Z, Zhong N, Peterson $\mathrm{S}$, Olsson $\mathrm{H}$. Maintenance therapy with budesonide and formoterol in chronic obstructive pulmonary disease. European Respiratory Journal 2003;22(6):912-9.

\section{Cochrane Handbook}

Higgins JPT, Green S (editors). Cochrane Handbook for Systematic Reviews of Interventions Version 5.0.1 [updated September 2008].. Available from www.cochranehandbook.org [Accessed 26th February 2009].

\section{Effing 2007}

Effing T, Monninkhof EEM, van der Valk PP, Zielhuis GGA, Walters EH, van der Palen JJ. Self-management education for patients with chronic obstructive pulmonary disease. Cochrane Database of Systematic Reviews 2007, Issue 4. [DOI: 10.1002/14651858.CD002990.pub2]

GOLD

Global Initiative for Chronic Obstructive Lung Disease. http://www.goldcopd.com [Accessed 18th February 2009].

\section{ICHE2a 1995}

Expert Working Group (Efficacy) of theInternational Conference on Harmonisation of Technical Requirements for Registrationof Pharmaceuticals for Human Use (ICH). Clinical safety data management: Definitions and standards for expedited reporting. http://www.fda.gov/cder/guidance/ iche2a.pdf 1995.

\section{Jones 2009}

Jones P W. Triple Therapy for Chronic Obstructive Pulmonary Disease Trials Catching Up with Clinical Practice?. American Journal of Respiratory and Critical Care Medicine 2009;180(8):689-90. 


\section{Karner 2011}

Karner C, Cates CJ. Combination inhaled steroid and long-acting beta2-agonist in addition to tiotropium versus tiotropium or combination alone for chronic obstructive pulmonary disease. Cochrane Database of Systematic Reviews 2011, Issue 6. [DOI: 10.1002/ 14651858.CD008532.pub2]

\section{Keene 2008}

Keene ON, Calverley PMA, Jones PW, Vestbo J, Anderson JA. Statistical analysis of exacerbation rates in COPD: TRISTAN and ISOLDE revisited. European Respiratory Journal 2008;32:17-24.

\section{Kesten 2007}

Kesten S, Plautz M, Piquette CA, Habib MP, Niewoehner DE. Premature discontinuation of patients: a potential bias in COPD clinical trials. European Respiratory Journal 2007; 30:898-906.

\section{Lacasse 2006}

Lacasse Y, Goldstein R, Lasserson TJ, Martin S. Pulmonary rehabilitation for chronic obstructive pulmonary disease. Cochrane Database of Systematic Reviews 2006, Issue 4. [DOI: 10.1002/14651858.CD003793.pub2]

\section{Nannini 2007a}

Nannini LJ, Cates CJ, Lasserson TJ, Poole P. Combined corticosteroid and long-acting beta2-agonist in one inhaler versus placebo for chronic obstructive pulmonary disease. Cochrane Database of Systematic Reviews 2007, Issue 4. [DOI: 10.1002/14651858.CD003794.pub3]

\section{Nannini 2007b}

Nannini LJ, Cates CJ, Lasserson TJ, Poole P. Combined corticosteroid and long-acting beta2-agonist in one inhaler versus long-acting beta2-agonists for chronic obstructive pulmonary disease. Cochrane Database of Systematic Reviews 2007, Issue 4. [DOI: 10.1002/14651858.CD006829]

\section{Nannini 2007c}

Nannini LJ, Cates CJ, Lasserson TJ, Poole P. Combined corticosteroid and long-acting beta2-agonist in one inhaler versus inhaled steroids for chronic obstructive pulmonary disease. Cochrane Database of Systematic Reviews 2007, Issue 4. [DOI: 10.1002/14651858.CD006826]
SGRQ

Jones P. St George Respiratory Questionnaire. http://www.healthstatus.sgul.ac.uk/downloads/ respiratory_questionairre.htm [accessed 6th October 2009].

\section{Singh 2008b}

Singh S, Loke YK, Furberg CD. Inhaled anticholinergics and risk of major adverse cardiovascular events in patients with chronic obstructive pulmonary disease: a systematic review and meta-analysis. JAMA 2008;300(12):1439-1450.

\section{Singh 2009}

Singh S, Amin AV, Loke YK. Long-term use of inhaled corticosteroids and the risk of pneumonia in chronic obstructive pulmonary disease. Archives of internal medicine 2009;169(3):219-29.

\section{Suissa 2008}

Suissa S, Ernst P, Vandemheen K L, Aaron S D.

Methodological issues in therapeutic trials of COPD. European Respiratory Journal 2008;31(5):927-33.

\section{Suissa 2008a}

Suissa S. Methodologic Shortcomings of the INSPIRE Randomized Trial. American Journal of Respiratory and Critical Care Medicine 2008;178(10):1090-b-1091.

\section{TORCH}

Calverley PM, Anderson JA, Celli B, Ferguson GT, Jenkins $\mathrm{C}$, Jones PW, et al.Salmeterol and fluticasone propionate and survival in chronic obstructive pulmonary disease. New England Journal of Medicine 2007; Vol. 356, issue 8: 775-89. [1533-4406: (Electronic)]

\section{UPLIFT}

Tashkin DP, Celli B, Senn S, Burkhart D, Kesten S, Menjoge S, et al.A 4-year trial of tiotropium in chronic obstructive pulmonary disease. New England Journal of Medicine 2008;359(15):1543-54.

\section{Yang 2007}

Yang IA, Fong K, Sim EH, Black PN, Lasserson TJ. Inhaled corticosteroids for stable chronic obstructive pulmonary disease. Cochrane Database of Systematic Reviews 2007, Issue 2. [DOI: 10.1002/14651858.CD002991.pub2]

* Indicates the major publication for the study 


\section{CHARACTERISTICS OF STUDIES}

\section{Characteristics of included studies [ordered by study ID]}

Dawber 2005

Design: A single centre, randomised, double-blind, double dummy, parallel group study
over three weeks from March to May 2004 in Germany
Run-in: Two weeks. Subjects discontinued their usual COPD medications. Participants
were given inhaled salbutamol VENTOLIN as a relief medication with a VOLUMATIC
spacer device

\begin{tabular}{|c|c|}
\hline Participants & $\begin{array}{l}\text { Population: } 59 \text { Adults with a clinical history of moderate or severe COPD }(30 \% \leq \\
\mathrm{FEV}_{1}>80 \% \text { predicted normal) } \\
\text { Baseline Characteristics: Mean age } 59 \text { years. } \\
\text { Inclusion Criteria: Smoking history of } \geq 10 \text { pack years. Females of child-bearing po- } \\
\text { tential were required to use adequate birth control methods } \\
\text { Exclusion Criteria: } \mathrm{FEV}_{1}>70 \% \text { predicted normal at baseline. Participants that were } \\
\text { unable to complete daily record card during run-in period or demonstrate correct use of } \\
\text { inhaler } \\
\text { All subjects received salbutamol as a relief medication delivered via a MDI and spacer }\end{array}$ \\
\hline Interventions & $\begin{array}{l}\text { 1. Combination of fluticasone } 500 \mu \mathrm{g} \text { and salmeterol } 50 \mu \mathrm{g} \text { twice a day via DISKUS } \\
\text { inhaler plus placebo capsules to match TIO delivered once daily via the Handihaler } \\
\text { inhaler. } \\
\text { 2. Tiotropium } 18 \mu \mathrm{g} \text { once a day via Handihaler plus placebo to match FPS } \\
\text { DISKUS combination product delivered twice daily. }\end{array}$ \\
\hline
\end{tabular}

Outcomes $\quad$ Primary Outcome: mucociliary clearance rate $\left(\mathrm{PPR}_{2.5}\right)$.

Secondary outcomes include: mucociliary clearance rate $\left(\mathrm{PPR}_{4}\right)$; mucociliary clearance as measured by the half life of the fast clearance slope; $\mathrm{FEV}_{1}, \mathrm{FVC}$, Raw, PEF, COPD symptoms.

Notes Sponsored by GlaxoSmithKline.

\section{Risk of bias}

\begin{tabular}{|c|c|c|}
\hline Bias & Authors' judgement & Support for judgement \\
\hline $\begin{array}{l}\text { Random sequence generation (selection } \\
\text { bias) }\end{array}$ & Low risk & $\begin{array}{l}\text { "Subjects were assigned to study treat- } \\
\text { ment in accordance with the randomisa- } \\
\text { tion schedule, which was generated, using } \\
\text { the GSK computer programme Patient Al- } \\
\text { location for Clinical Trials (PACT)." }\end{array}$ \\
\hline Allocation concealment (selection bias) & Low risk & $\begin{array}{l}\text { "Subjects were assigned to study treat- } \\
\text { ment in accordance with the randomisa- } \\
\text { tion schedule, which was generated, using } \\
\text { the GSK computer programme Patient Al- } \\
\text { location for Clinical Trials (PACT)." }\end{array}$ \\
\hline
\end{tabular}


Dawber 2005 (Continued)

\begin{tabular}{l|l|l}
$\begin{array}{l}\text { Blinding (performance bias and detection } \\
\text { bias) } \\
\text { All outcomes }\end{array}$ & Low risk & $\begin{array}{l}\text { "Double-blind double dummy." } \\
\text { The active tiotropium bromide capsules } \\
\text { and the placebo capsules were notice- } \\
\text { ably different so returned medication was } \\
\text { logged by someone not directly involved in } \\
\text { the study } \\
\text { Unblinding was permitted only for clini- } \\
\text { cal management, welfare of the subject or } \\
\text { for serious adverse events and GSK were } \\
\text { not notified of the withdrawee's treatment } \\
\text { allocation. Decisions to withdraw subjects } \\
\text { due to adverse events were made before un- } \\
\text { blinding } \\
\text { "Neither the subject nor the investigator } \\
\text { knew which treatment had been assigned } \\
\text { to each subject. The investigator was, how- } \\
\text { ever, supplied with a sealed envelope con- } \\
\text { taining the code break for the subjects for } \\
\text { emergency use." }\end{array}$ \\
\hline
\end{tabular}

\section{INSPIRE}

Methods

Participants
Design: A randomised, double-blind, double-dummy, multi-centre, parallel-group study over 104 weeks from June 2003 to February 2006 at 173 centres in 20 European countries. (Austria, Belgium, Czech Republic, Denmark, Estonia, Germany, Greece, Italy, Latvia, Lithuania, Netherlands, Norway, Romania, Russia, Slovak Republic, Slovenia, Spain, Sweden, Ukraine and the UK)

Run-in: Two weeks on oral prednisolone and salmeterol.

Population: 1,323 adults with a clinical history of severe and very severe COPD (GOLD stage III and IV). $\mathrm{FEV}_{1}$ less than $50 \%$ for inclusion into the trial.

Baseline Characteristics: Mean age 64 years. FEV $_{1}$ 39\% predicted. Inhaled corticosteroids used previously by $50 \%$ of participants. Exacerbation in previous 12 months in $86 \%$ of participants. $48 \%$ of participants on FPS and $51 \%$ on tiotropium stopped taking inhaled corticosteroids at baseline

Inclusion Criteria: Aged 40 to 80 years, with a smoking history of 10 or more packyears, a clinical history of COPD exacerbations, post-bronchodilator $\mathrm{FEV}_{1}$ less than $50 \%$ of predicted, bronchodilator reversibility of less than $10 \%$ in $\mathrm{FEV}_{1}$ to $400 \mathrm{mg}$ salbutamol, score of 2 or more on the Modified Medical Research Council dyspnea scale. Exclusion Criteria: Asthma or atopic disease, a lung disease likely to confound the drug response other than COPD, a recent exacerbation (within 6 weeks of screening or during run-in); receiving long-term oxygen therapy or pulmonary rehabilitation or had a known or suspected hypersensitivity to beta 2 -agonists, inhaled corticosteroids, anticholinergic agents or any components of these formulations 
INSPIRE (Continued)

\begin{tabular}{l|l}
\hline Interventions & $\begin{array}{l}\text { 1. Combination of fluticasone } 500 \mu \mathrm{g} \text { and salmeterol } 50 \mu \mathrm{g} \text { twice a day via } \\
\text { DISKUS/ACCUHALER inhaler plus placebo capsules to match TIO delivered once } \\
\text { daily via the Handihaler inhaler. } \\
\text { 2. Tiotropium } 18 \mu \mathrm{g} \text { once a day via Handihaler plus placebo to match FPS } \\
\text { DISKUS/ACCUHALER combination product delivered twice daily. }\end{array}$ \\
\hline Outcomes & $\begin{array}{l}\text { Primary outcome: To compare the rate of health care utilization (HCU) COPD exacer- } \\
\text { bations in those using fluticasone/salmeterol }(500 / 50 \mu \mathrm{g}) \text { versus those using tiotropium } \\
18 \mu \mathrm{g}\end{array}$ \\
\hline Notes & $\begin{array}{l}\text { Sponsored by GlaxoSmithKline. } \\
\text { Participants were allowed to use short-acting inhaled beta2-agonists and standardised } \\
\text { short courses of oral corticosteroids }\end{array}$ \\
\hline
\end{tabular}

Risk of bias

\begin{tabular}{|c|c|c|}
\hline Bias & Authors' judgement & Support for judgement \\
\hline $\begin{array}{l}\text { Random sequence generation (selection } \\
\text { bias) }\end{array}$ & Low risk & $\begin{array}{l}\text { Computer generated central randomisa- } \\
\text { tion list. Stratified allocation by centre and } \\
\text { smoking. Block size of four }\end{array}$ \\
\hline Allocation concealment (selection bias) & Low risk & $\begin{array}{l}\text { Telephone interactive voice response sys- } \\
\text { tem. }\end{array}$ \\
\hline $\begin{array}{l}\text { Blinding (performance bias and detection } \\
\text { bias) } \\
\text { All outcomes }\end{array}$ & Low risk & $\begin{array}{l}\text { Double blind, double dummy design. } \\
\text { Due to a difference in appearance between } \\
\text { tiotropium bromide and placebo inhala- } \\
\text { tion capsules, study medication was dis- } \\
\text { pensed by someone not directly involved in } \\
\text { trial. Neither the investigator nor site per- } \\
\text { sonnel were present when the subject ad- } \\
\text { ministered his/her study medication. Sub- } \\
\text { jects were instructed not to show their } \\
\text { study medication to other subjects. De- } \\
\text { cisions to withdraw subjects due to ad- } \\
\text { verse events were made before unblinding. } \\
\text { Subjects were unblinded only in emergen- } \\
\text { cies where knowledge of the investigational } \\
\text { product was essential for the clinical man- } \\
\text { agement or welfare of the subject. Emer- } \\
\text { gency unblinding was done via an auto- } \\
\text { mated telephone system. }\end{array}$ \\
\hline
\end{tabular}

Incomplete outcome data (attrition bias) High risk All outcomes
On FPS 35\% withdrew from the study and on tiotropium $42 \%$ withdrew. Trialists provided an adequate breakdown of reasons for withdrawal. Differential withdrawal rates 
Methods

Participants
Design: A randomised, double-blind, double-dummy, multi-centre, parallel-group exploratory study over 12 weeks from March 2003 to October 2003 at 17 centres in the Netherlands

Run in: All oral, slow-release and long-acting beta 2 -agonists, inhaled corticosteroids, anticholinergics and short-acting beta2-agonists were discontinued. Subjects were issued with either a VENTOLIN DISKUS/ACCUHALER inhaler (200 $\mu \mathrm{g}$ /actuation) or VENTOLIN MDI (100 $\mu \mathrm{g}$ /actuation) plus VOLUMATIC spacer for use as relief medication

Population: 125 adults with a clinical history of moderate to severe COPD as defined by the Global Initiative for Obstructive Lung Disease 2001 guidelines

Inclusion Criteria: Aged 40-80 years inclusive. Post-bronchodilator $\mathrm{FEV}_{1}$ less than $70 \%$ of predicted normal. Subjects must have had a smoking history (current or former smokers) of more than 10 pack-years. Mean $\mathrm{FEV}_{1} 1.4 \mathrm{~L}$.

Exclusion Criteria: Within four weeks prior to visit one; COPD exacerbation; received oral, parenteral, or depot corticosteroids for a COPD exacerbation; received antibiotic therapy and/or been hospitalised for either a lower respiratory tract infection or for COPD exacerbation, or had any changes in their COPD medication

Interventions

1. Combination of fluticasone $500 \mu \mathrm{g}$ and salmeterol $50 \mu \mathrm{g}$ twice a day via DISKUS inhaler plus placebo capsules to match TIO delivered once daily via the Handihaler inhaler.

2. Tiotropium $18 \mu \mathrm{g}$ once a day via Handihaler plus placebo to match FPS DISKUS combination product delivered twice daily.

Outcomes

No primary outcomes as this was an exploratory study.

\section{Notes}

Sponsored by GlaxoSmithKline.

\section{Risk of bias}

\begin{tabular}{|c|c|c|}
\hline Bias & Authors' judgement & Support for judgement \\
\hline $\begin{array}{l}\text { Random sequence generation (selection } \\
\text { bias) }\end{array}$ & Low risk & $\begin{array}{l}\text { "At randomisation (Visit } 2 / 2 \mathrm{~A} \text { ) all eligible } \\
\text { subjects were randomly assigned to treat- } \\
\text { ment by use of a Registration and Mate- } \\
\text { rial Ordering System (RAMOS) which uti- } \\
\text { lized an IVRS developed by GSK. Subjects } \\
\text { were assigned to a unique treatment num- } \\
\text { ber." "Random allocation to study drug was } \\
\text { stratified according to smoking status of } \\
\text { subjects at entry (current smoker, former } \\
\text { smoker) on a } 1: 1 \text { basis." }\end{array}$ \\
\hline
\end{tabular}


SCO40034 (Continued)

\begin{tabular}{|c|c|c|}
\hline Allocation concealment (selection bias) & Low risk & $\begin{array}{l}\text { "The treatment number was an identifica- } \\
\text { tion number for the blinded study medi- } \\
\text { cation and was assigned from a randomi- } \\
\text { sation schedule provided by GSK. This } \\
\text { schedule was generated by a GSK ran- } \\
\text { domisation program, Patient Allocation for } \\
\text { Clinical Trials (PACT) and then stored in } \\
\text { another GSK program known as RandAll. } \\
\text { Treatment numbers were not assigned to a } \\
\text { subject without contacting RAMOS, and } \\
\text { once a treatment number had been assigned } \\
\text { to a subject, it was not reassigned to an- } \\
\text { other subject in this study." }\end{array}$ \\
\hline $\begin{array}{l}\text { Blinding (performance bias and detection } \\
\text { bias) } \\
\text { All outcomes }\end{array}$ & Low risk & $\begin{array}{l}\text { "Double blind double dummy." } \\
\text { There was a difference between the active } \\
\text { tiotropium bromide and matching placebo } \\
\text { capsules. Therefore someone who was not } \\
\text { directly involved in the study received and } \\
\text { documented all returned medication in a } \\
\text { drug accountability log, a separate account- } \\
\text { ability log was maintained for each subject } \\
\text { and subjects administered their own study } \\
\text { medication without the investigator or site } \\
\text { personnel being present } \\
\text { Subjects were unblinded only when knowl- } \\
\text { edge of the treatment was essential for } \\
\text { the clinical management or welfare of } \\
\text { the subject. Cases of unblinding were } \\
\text { to be reported and documented immedi- } \\
\text { ately. Pateients experiencing serious adverse } \\
\text { events were unblinded. Decisions by the in- } \\
\text { vestigator to withdraw the subject due to an } \\
\text { AE were made before unblinding. Blinded } \\
\text { study drug was supplied in treatment packs } \\
\text { at Visits } 2 / 2 \mathrm{~A}, 4 \text { and } 5 \text {. The content of each } \\
\text { treatment pack was detailed on the outer } \\
\text { packaging }\end{array}$ \\
\hline $\begin{array}{l}\text { Incomplete outcome data (attrition bias) } \\
\text { All outcomes }\end{array}$ & High risk & $\begin{array}{l}117 / 125(94 \%) \text { Completed the study, but } \\
\text { withdrawals were imbalanced with one } \\
\text { from the FPS arm and seven from the } \\
\text { tiotropium arm }\end{array}$ \\
\hline
\end{tabular}


Characteristics of excluded studies [ordered by study ID]

\begin{tabular}{ll}
\hline Study & Reason for exclusion \\
\hline Bateman 2008 & This pilot study compared separate fluticasone and salmeterol inhalers to tiotropium \\
\hline Golabi 2006 & Study of cross-over design. \\
\hline Hara 2007 & Study of cross-over design. \\
\hline Singh 2008 & Study of cross-over design. \\
\hline
\end{tabular}


DATA AND ANALYSES

Comparison 1. Fluticasone/Salmeterol (FPS) versus Tiotropium (Tio)

\begin{tabular}{|c|c|c|c|c|}
\hline Outcome or subgroup title & $\begin{array}{l}\text { No. of } \\
\text { studies }\end{array}$ & $\begin{array}{c}\text { No. of } \\
\text { participants }\end{array}$ & Statistical method & Effect size \\
\hline 1 Mortality (All-cause) & 3 & & Peto Odds Ratio (Peto, Fixed, 95\% CI) & Totals not selected \\
\hline 2 Hospital Admission & 3 & & Peto Odds Ratio (Peto, Fixed, 95\% CI) & Totals not selected \\
\hline $\begin{array}{l}2.1 \text { Hospital admissions all } \\
\text { cause }\end{array}$ & 3 & & Peto Odds Ratio (Peto, Fixed, 95\% CI) & $0.0[0.0,0.0]$ \\
\hline $\begin{array}{l}2.2 \text { Hospital admissions } \\
\text { resulting from exacerbations }\end{array}$ & 1 & & Peto Odds Ratio (Peto, Fixed, 95\% CI) & $0.0[0.0,0.0]$ \\
\hline $\begin{array}{l}3 \text { Exacerbations (all cause): number } \\
\text { of patients experiencing one or } \\
\text { more exacerbations over two } \\
\text { years }\end{array}$ & 1 & & Odds Ratio (M-H, Fixed, 95\% CI) & Totals not selected \\
\hline $\begin{array}{l}4 \text { Exacerbations (mean number of } \\
\text { exacerbations per patient per } \\
\text { year) }\end{array}$ & 1 & & Rate Ratio (Fixed, 95\% CI) & Totals not selected \\
\hline 4.1 Exacerbations (all cause) & 1 & & Rate Ratio (Fixed, 95\% CI) & $0.0[0.0,0.0]$ \\
\hline $\begin{array}{l}\text { 4.2 Exacerbations requiring } \\
\text { oral corticosteroids }\end{array}$ & 1 & & Rate Ratio (Fixed, 95\% CI) & $0.0[0.0,0.0]$ \\
\hline $\begin{array}{l}4.3 \text { Exacerbations requiring } \\
\text { antibiotics }\end{array}$ & 1 & & Rate Ratio (Fixed, 95\% CI) & $0.0[0.0,0.0]$ \\
\hline 5 Pneumonia & 3 & & Peto Odds Ratio (Peto, Fixed, 95\% CI) & Totals not selected \\
\hline 6 Quality of Life & 1 & & Mean Difference (Fixed, 95\% CI) & Totals not selected \\
\hline 6.132 weeks & 1 & & Mean Difference (Fixed, 95\% CI) & $0.0[0.0,0.0]$ \\
\hline 6.2104 weeks & 1 & & Mean Difference (Fixed, 95\% CI) & $0.0[0.0,0.0]$ \\
\hline $7 \mathrm{FEV}_{1}$ (Litres) & 3 & & Mean Difference (Fixed, 95\% CI) & Totals not selected \\
\hline $\begin{array}{l}\text { 7.1 } \mathrm{FEV}_{1} \text { at short time frame } \\
\text { (3 to } 12 \text { weeks) }\end{array}$ & 3 & & Mean Difference (Fixed, 95\% CI) & $0.0[0.0,0.0]$ \\
\hline 7.2 $\mathrm{FEV}_{1}$ at 2 years & 1 & & Mean Difference (Fixed, 95\% CI) & $0.0[0.0,0.0]$ \\
\hline $\begin{array}{l}8 \text { Serious Adverse Events } \\
\quad \text { (non-fatal) }\end{array}$ & 3 & & Peto Odds Ratio (Peto, Fixed, 95\% CI) & Totals not selected \\
\hline 9 Adverse Events & 3 & & Peto Odds Ratio (Peto, Fixed, 95\% CI) & Totals not selected \\
\hline 10 Withdrawal & 3 & & Peto Odds Ratio (Peto, Fixed, 95\% CI) & Totals not selected \\
\hline $\begin{array}{l}\text { 10.1 Total number of subjects } \\
\text { withdrawn }\end{array}$ & 3 & & Peto Odds Ratio (Peto, Fixed, 95\% CI) & $0.0[0.0,0.0]$ \\
\hline 10.2 Due to adverse events & 3 & & Peto Odds Ratio (Peto, Fixed, 95\% CI) & $0.0[0.0,0.0]$ \\
\hline 10.3 Due to lack of efficacy & 3 & & Peto Odds Ratio (Peto, Fixed, 95\% CI) & $0.0[0.0,0.0]$ \\
\hline
\end{tabular}


Analysis I.I. Comparison I Fluticasone/Salmeterol (FPS) versus Tiotropium (Tio), Outcome I Mortality (All-cause).

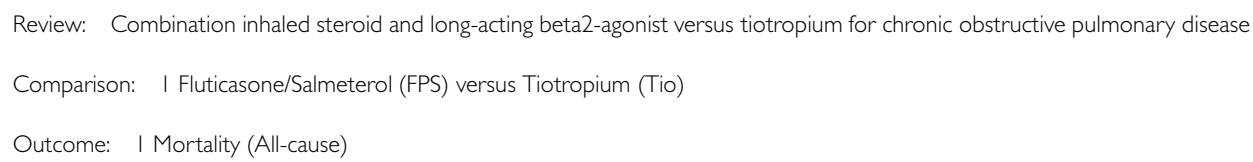

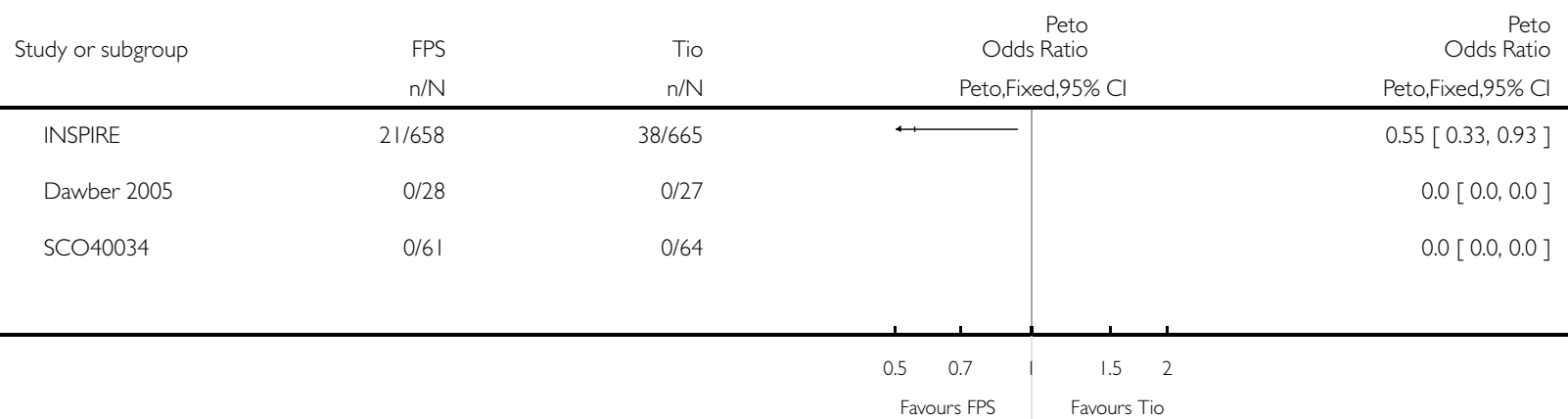

\section{Analysis I.2. Comparison I Fluticasone/Salmeterol (FPS) versus Tiotropium (Tio), Outcome 2 Hospital} Admission.

Review: Combination inhaled steroid and long-acting beta2-agonist versus tiotropium for chronic obstructive pulmonary disease

Comparison: I Fluticasone/Salmeterol (FPS) versus Tiotropium (Tio)

Outcome: 2 Hospital Admission

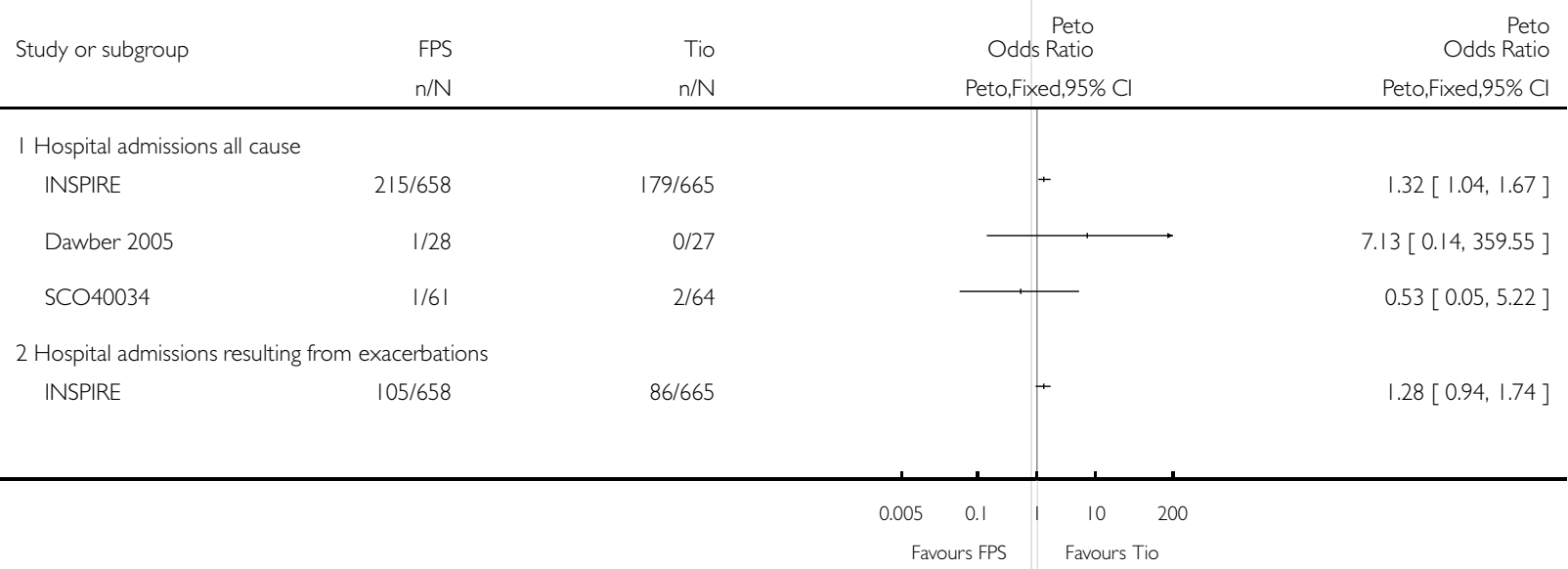


Analysis I.3. Comparison I Fluticasone/Salmeterol (FPS) versus Tiotropium (Tio), Outcome 3 Exacerbations (all cause): number of patients experiencing one or more exacerbations over two years.

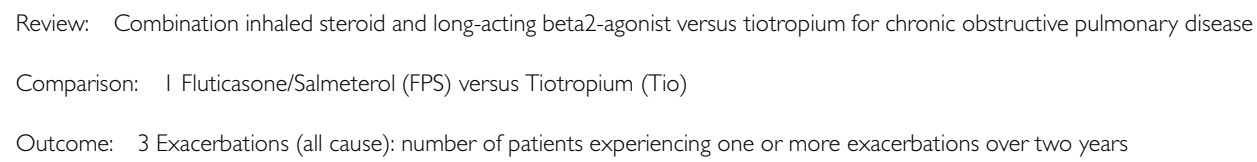

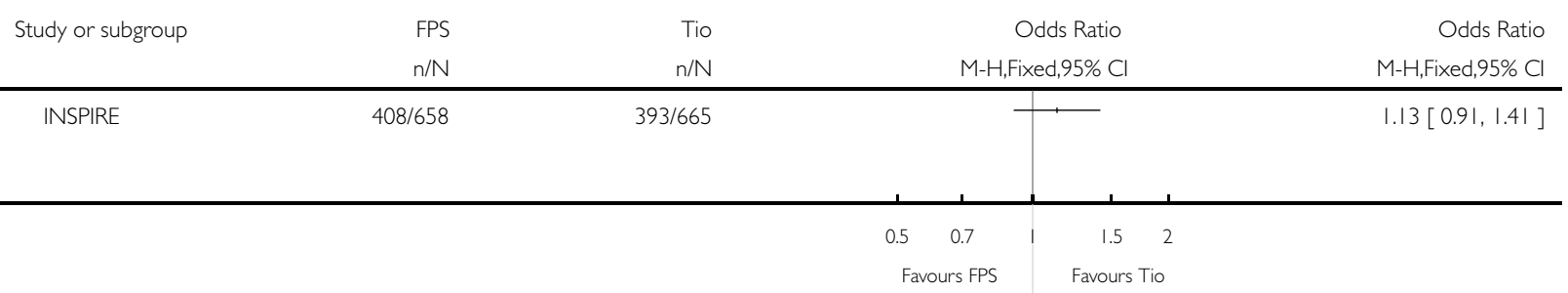

Analysis I.4. Comparison I Fluticasone/Salmeterol (FPS) versus Tiotropium (Tio), Outcome 4 Exacerbations (mean number of exacerbations per patient per year).

Review: Combination inhaled steroid and long-acting beta2-agonist versus tiotropium for chronic obstructive pulmonary disease

Comparison: I Fluticasone/Salmeterol (FPS) versus Tiotropium (Tio)

Outcome: 4 Exacerbations (mean number of exacerbations per patient per year)

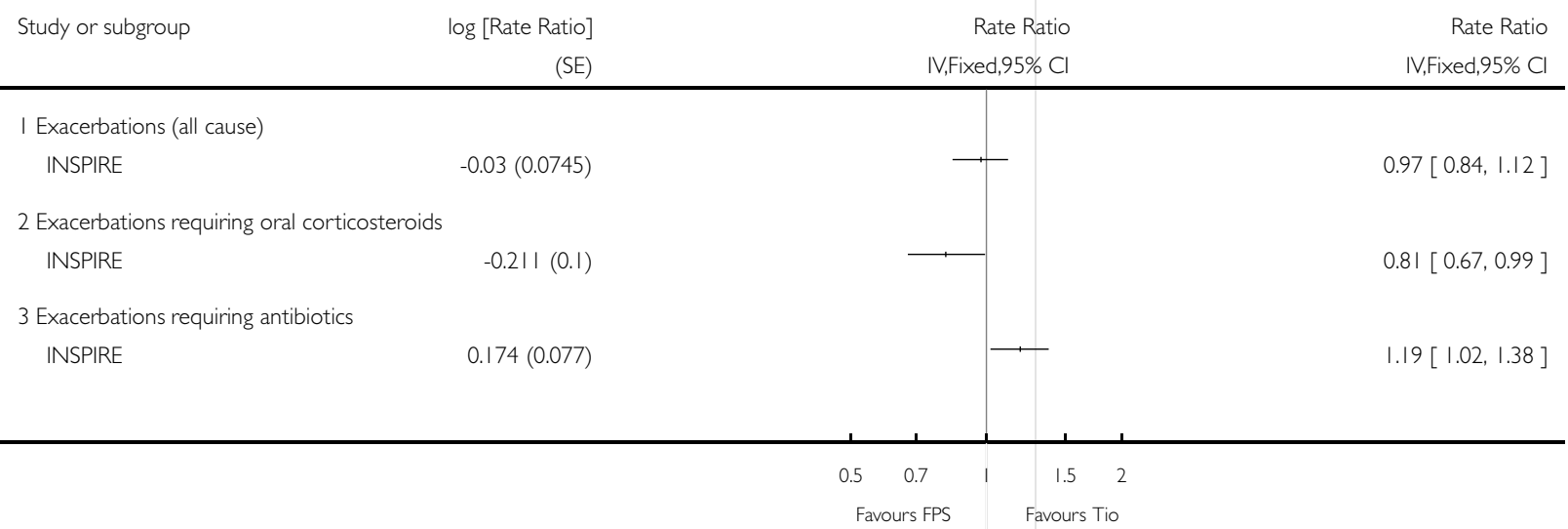




\section{Analysis I.5. Comparison I Fluticasone/Salmeterol (FPS) versus Tiotropium (Tio), Outcome 5 Pneumonia.}

Review: Combination inhaled steroid and long-acting beta2-agonist versus tiotropium for chronic obstructive pulmonary disease

Comparison: I Fluticasone/Salmeterol (FPS) versus Tiotropium (Tio)

Outcome: 5 Pneumonia

\begin{tabular}{|c|c|c|c|c|}
\hline \multirow[t]{2}{*}{ Study or subgroup } & & \multicolumn{2}{|r|}{$\begin{array}{r}\text { Peto } \\
\text { Odds Ratio }\end{array}$} & \multirow{2}{*}{$\begin{array}{r}\text { Peto } \\
\text { Odds Ratio } \\
\text { Peto,Fixed,95\% Cl }\end{array}$} \\
\hline & $\mathrm{n} / \mathrm{N}$ & $\mathrm{n} / \mathrm{N}$ & Peto,Fixed,95\% Cl & \\
\hline INSPIRE & $50 / 658$ & $24 / 665$ & + & $2.13[1.33,3.40]$ \\
\hline Dawber 2005 & $1 / 28$ & $0 / 27$ & 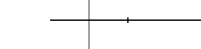 & $7.13[0.14,359.55]$ \\
\hline SCO40034 & $0 / 61$ & $0 / 64$ & & $0.0[0.0,0.0]$ \\
\hline
\end{tabular}

Analysis I.6. Comparison I Fluticasone/Salmeterol (FPS) versus Tiotropium (Tio), Outcome 6 Quality of Life.

Review: Combination inhaled steroid and long-acting beta2-agonist versus tiotropium for chronic obstructive pulmonary disease

Comparison: I Fluticasone/Salmeterol (FPS) versus Tiotropium (Tio)

Outcome: 6 Quality of Life

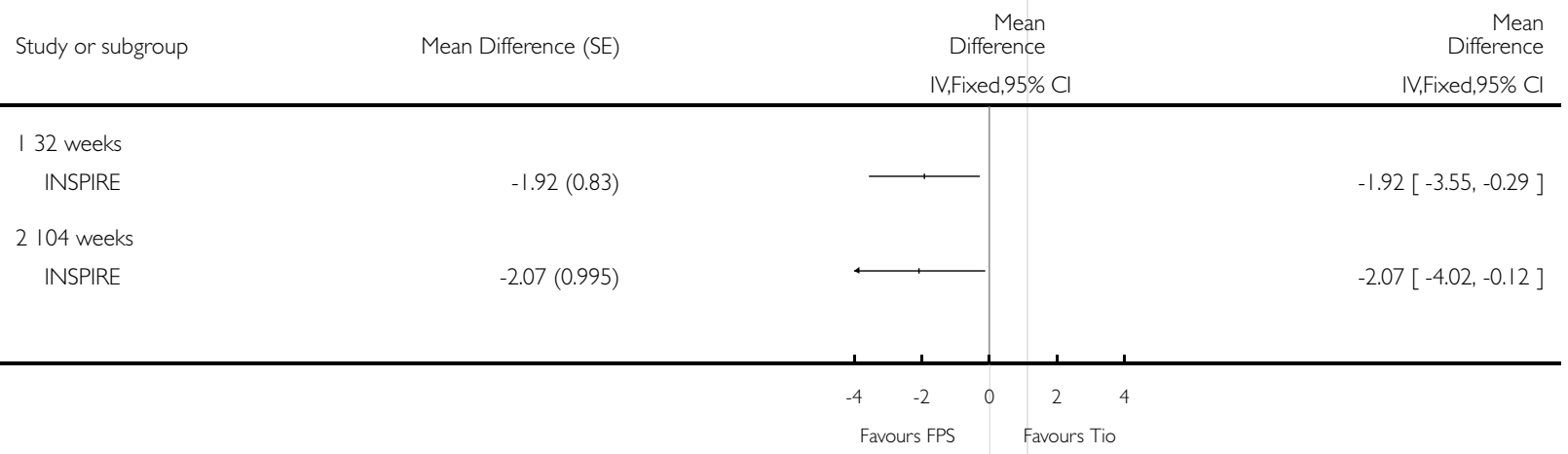


Analysis I.7. Comparison I Fluticasone/Salmeterol (FPS) versus Tiotropium (Tio), Outcome 7 FEV 1 (Litres).

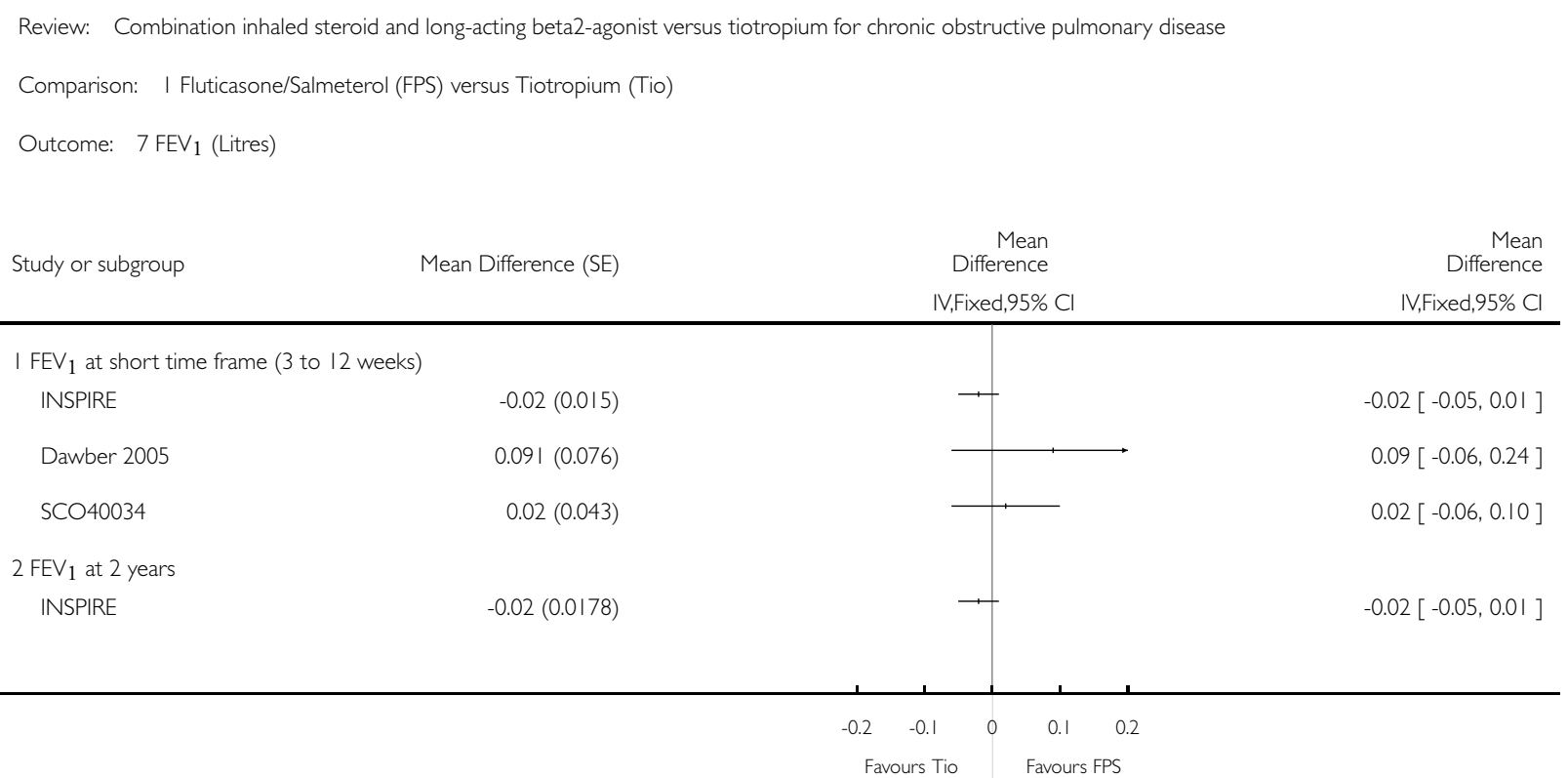

\section{Analysis I.8. Comparison I Fluticasone/Salmeterol (FPS) versus Tiotropium (Tio), Outcome 8 Serious} Adverse Events (non-fatal).

Review: Combination inhaled steroid and long-acting beta2-agonist versus tiotropium for chronic obstructive pulmonary disease

Comparison: I Fluticasone/Salmeterol (FPS) versus Tiotropium (Tio)

Outcome: 8 Serious Adverse Events (non-fatal)

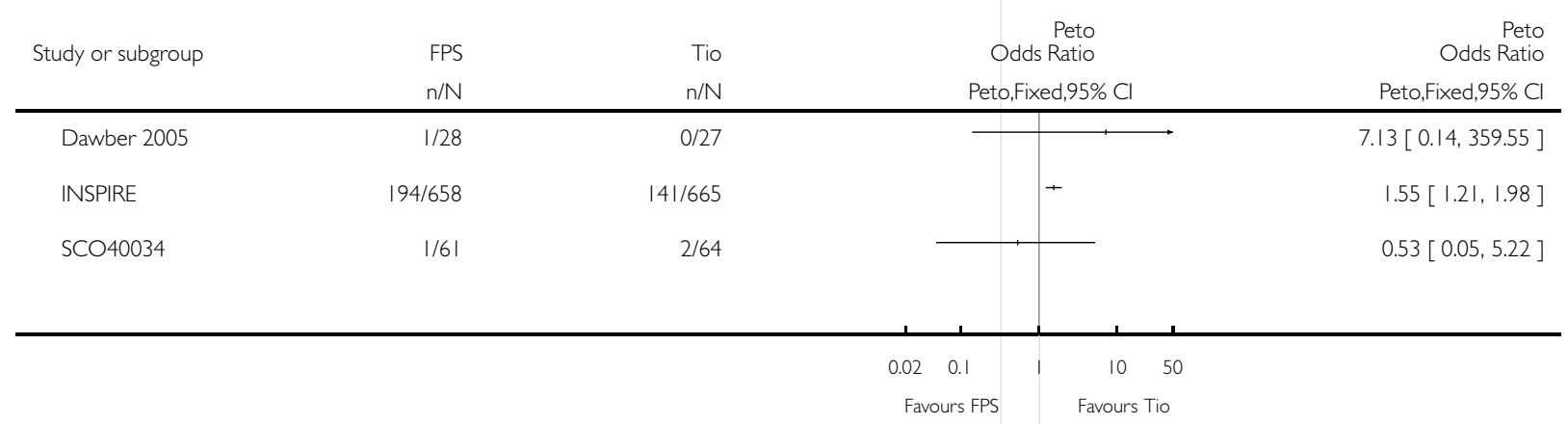


Analysis I.9. Comparison I Fluticasone/Salmeterol (FPS) versus Tiotropium (Tio), Outcome 9 Adverse Events.

Review: Combination inhaled steroid and long-acting beta2-agonist versus tiotropium for chronic obstructive pulmonary disease

Comparison: I Fluticasone/Salmeterol (FPS) versus Tiotropium (Tio)

Outcome: 9 Adverse Events

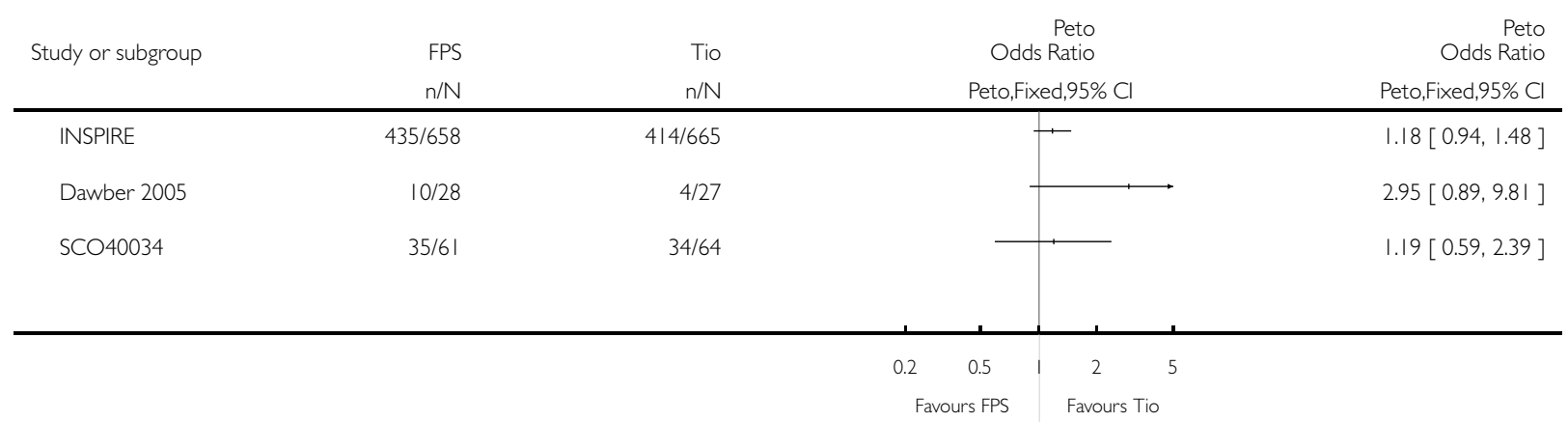

\section{Analysis I.I0. Comparison I Fluticasone/Salmeterol (FPS) versus Tiotropium (Tio), Outcome I0} Withdrawal.

Review: Combination inhaled steroid and long-acting beta2-agonist versus tiotropium for chronic obstructive pulmonary disease

Comparison: I Fluticasone/Salmeterol (FPS) versus Tiotropium (Tio)

Outcome: 10 Withdrawal

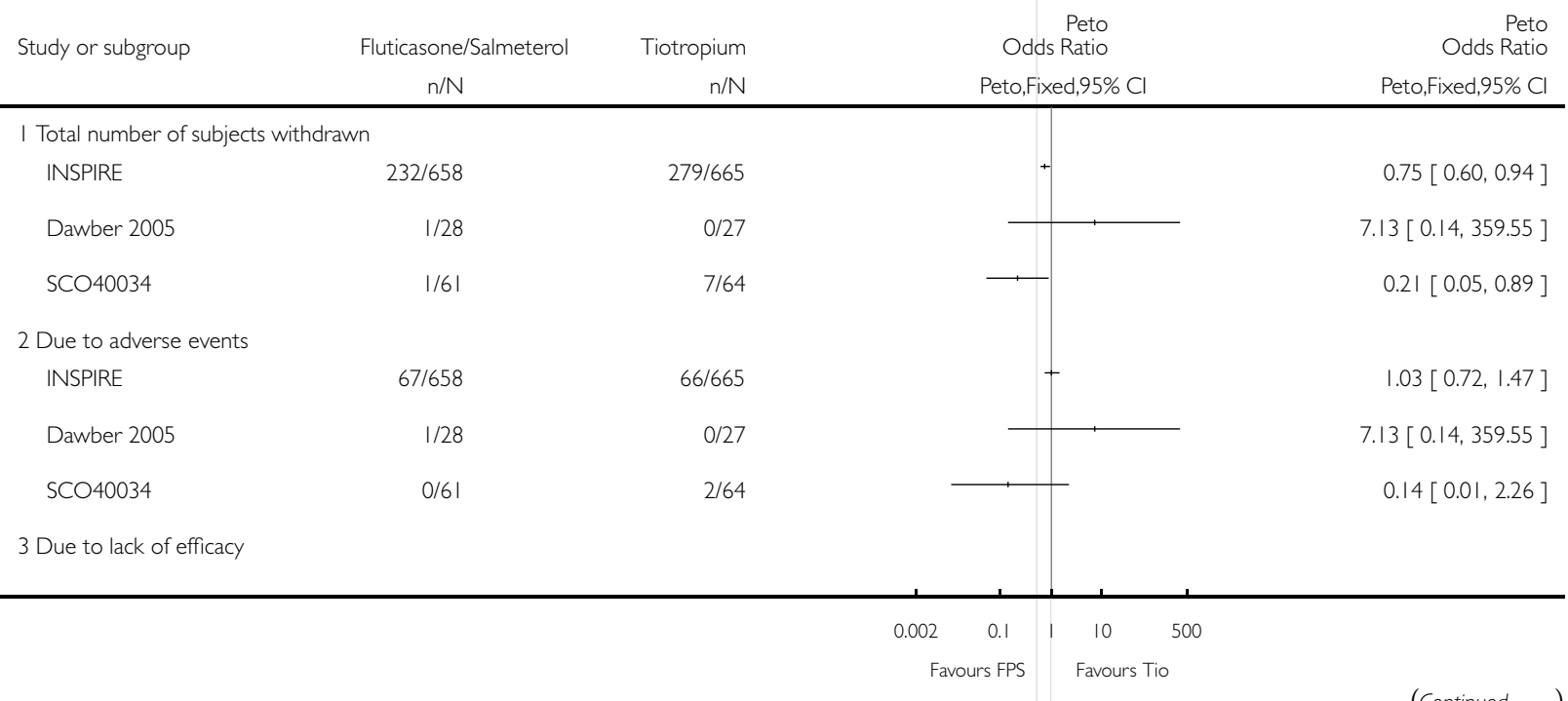

(Continued ...) 


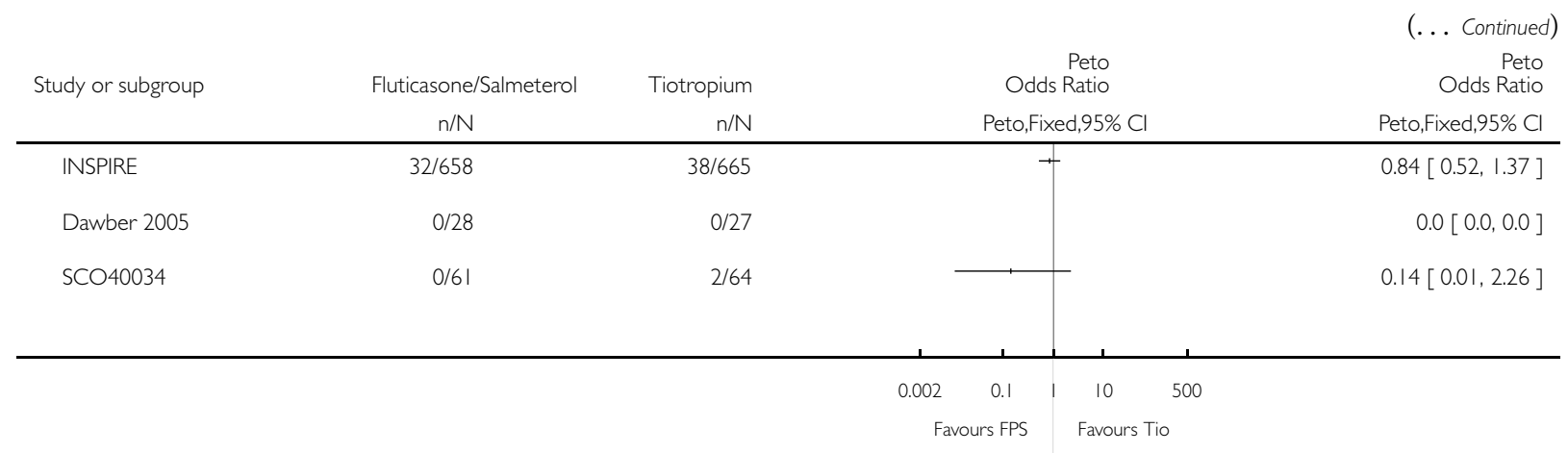

ADDITIONAL TABLES

Table 1. Differences in the reported cases of pneumonia in the INSPIRE trial

\begin{tabular}{l|l|l}
\hline & $\begin{array}{l}\text { Pneumonias recorded in patients treated } \\
\text { with fluticasone/salmeterol } \\
\text { number (\%) }\end{array}$ & $\begin{array}{l}\text { Pneumonias recorded in patients treated } \\
\text { with tiotropium } \\
\text { number (\%) }\end{array}$ \\
\hline $\begin{array}{l}\text { Most frequent adverse effects on ITT } \\
\text { population* }\end{array}$ & $43(7)$ & $23(3)$ \\
\hline Serious adverse events* & $37(6)$ & $22(3)$ \\
\hline Fatal serious adverse events* & $3(<1)$ & 0 \\
\hline $\begin{array}{l}\text { Adverse events including pneumonia, lo- } \\
\text { bar pneumonia and bronchopneumo- } \\
\text { nia** }\end{array}$ & $50(8)$ & $24(4)$ \\
\hline
\end{tabular}

* reported in SCO40035

** reported in Wedzicha 2008

Table 2. Reasons for withdrawals from INSPIRE

\begin{tabular}{l|l|l}
\hline Reason for withdrawal & Fluticasone/Salmeterol & Tiotropium \\
\hline Adverse event & 67 & 66 \\
\hline 'Withdrew consent & 61 & 82 \\
\hline Lost to follow-up & 15 & 13 \\
\hline Protocol violation & 7 & 8
\end{tabular}


Table 2. Reasons for withdrawals from INSPIRE (Continued)

\begin{tabular}{|c|c|c|}
\hline Failed entry criteria & 0 & 3 \\
\hline COPD exacerbation & 37 & 51 \\
\hline Lack of efficacy & 32 & 38 \\
\hline Other & 13 & 17 \\
\hline Missing & 0 & 1 \\
\hline Total & $232(35.3 \%)$ & $279(42.0 \%)$ \\
\hline
\end{tabular}

Table 3. Proportion of participants developing pneumonia

\begin{tabular}{lllllll}
\hline Study & Pneumonia on & $\begin{array}{l}\text { Comparison } \\
\text { treatment }\end{array}$ & $\begin{array}{l}\text { Pneumo- } \\
\text { nia on compari- } \\
\text { son treatment }\end{array}$ & $\begin{array}{l}\text { Trial duration, } \\
\text { weeks }\end{array}$ & $\begin{array}{l}\text { Pneumo- } \\
\text { nia on FPS per } \\
\mathbf{5 2} \text { weeks }\end{array}$ & $\begin{array}{l}\text { Pneumomia on } \\
\text { comparison per } \\
\mathbf{5 2} \text { weeks }\end{array}$ \\
\hline Naninni $2007 \mathrm{a}^{\dagger}$ & $325 / 2673(12 \%)$ & Placebo & $194 / 2556(8 \%)$ & $105^{*}$ & $5.9 \%$ & $4.0 \%$ \\
\hline TORCH & $303 / 1546(20 \%)$ & Placebo & $164 / 1544(11 \%)$ & 156 & $6.7 \%$ & $3.7 \%$ \\
\hline Naninni $2007 \mathrm{~b}^{\dagger}$ & $337 / 3334(10 \%)$ & LABA & $226 / 3329(7 \%)$ & $92^{*}$ & $5.7 \%$ & $4.0 \%$ \\
\hline TORCH & $303 / 1546(20 \%)$ & LABA & $205 / 1542(13 \%)$ & 156 & $6.7 \%$ & $4.3 \%$ \\
\hline INSPIRE & $50 / 658(8 \%)$ & Tiotropium & $24 / 665(4 \%)$ & 104 & $3.8 \%$ & $1.8 \%$ \\
\hline
\end{tabular}

${ }^{\dagger}$ Includes data from TORCH

*Weighted mean trial duration 


\section{A P P E N D I CES}

\section{Appendix I. Definition of Serious Adverse Events}

The Expert Working Group (Efficacy) of the International Conference on Harmonisation of Technical Requirements for Registration of Pharmaceuticals for Human Use (ICH) define serious adverse events as follows (ICHE2a 1995):

"A serious adverse event (experience) or reaction is any untoward medical occurrence that at any dose:

- Results in death,

- Is life-threatening,

- Requires inpatient hospitalisation or prolongation of existing hospitalisation,

- Results in persistent or significant disability/incapacity, or

- Is a congenital anomaly/birth defect.

NOTE: The term "life-threatening" in the definition of "serious" refers to an event in which the patient was at risk of death at the time of the event; it does not refer to an event which hypothetically might have caused death if it were more severe.”

\section{F E E D B A C K}

\section{Clarification on mortality data and analysis of exacerbation rates requested, 10 January 20 I I}

\section{Summary}

We have read this important review with great interest. In our assessment of the review we have several questions/comments.

1. It is stated that the INSPIRE trial investigators did not collect outcome events for patients who withdrew during the course of the study. We looked at the original INSPIRE publication (Wedzicha 2008) to confirm that this was the case. The INSPIRE investigators state "Mortality data was not collected after patients withdrew from therapy as in the TORCH (Toward a Revolution in COPD Health) study." This does not specifically state that other outcome events such as exacerbations were not collected for patients who withdrew prematurely. We wanted to know if this point was clarified with Wedzicha et al. We had assumed exacerbations were collected if they occurred after withdrawal but now we are not sure. Your help would be greatly appreciated.

2. For the INSPIRE trial rate ratios (RR) are given for the exacerbation analyses. We are not sure that sufficient explanations were given as to the difference in interpretation between rate ratios and relative risk ratios. This would be useful for clinician readers to know.

3. We congratulate the authors of this review for stating that conclusions are difficult to draw when there is so much missing data.

\section{Reply}

1. We did not confirm whether or not the trialists collected data on outcomes other than mortality in patients who withdrew therapy with the trialists before publication of this systematic review. Since receiving this feedback, we have been in contact with the pharmaceutical company who confirmed that there was no follow-up of patents if they withdrew form the study for other outcome data such as exacerbations. Because patents were followed up until the resolution of a serious adverse event, there is some limited mortality data for deaths which occurred after cessation of treatment which the trialist confirmed was reported in the original publication and therefore this review.

2. The main difference between Rate Ratios and Risk Ratios (or Odds Ratios), is that Rate Ratios include multiple exacerbations from individual patients, whereas the unit of analysis for Risk and Odds ratios is patients with one or more exacerbations. We have now included a forest plot to indicate the result achieved using Odds Ratios and have added a discussion around the differences in reporting is included in the Discussion section.

We thank Aaron and Elsa for their comments, in particular the second comment which allowed us to explain the issue of rate ratio versus relative risk ratios within our review 


\section{Contributors}

Aaron M Tejani and Elsa Liu

Submitter agrees with default conflict of interest statement: I certify that I have no affiliations with or involvement in any organization or entity with a financial interest in the subject matter of my feedback.

\section{WHAT'S NEW}

Last assessed as up-to-date: 7 October 2009.

\begin{tabular}{lll}
\hline Date & Event & Description \\
\hline 1 June 2011 & Feedback has been incorporated & $\begin{array}{l}\text { We included an analysis of exacerbations using odds ratios and compared this to } \\
\text { the rate ratio analysis we originally presented. Please see Discussion and Feedback. }\end{array}$ \\
\hline 1 June 2011 & Amended & Feedback incorporated \\
\hline
\end{tabular}

\section{H I S T O R Y}

Protocol first published: Issue 3, 2009

Review first published: Issue 5, 2010

\section{CONTRIBUTIONSOFAUTHORS}

Studies were assessed by CJC and EJW. CJC and EJW extracted data and entered it into RevMan, conducted the analysis. EJW wrote the review with input from CJC, \& PP.

CJC and PP developed the protocol.

Toby Lasserson was an author on the protocol but is not an author on the review.

\section{DECLARATIONS OF INTEREST}

None known.

\section{SOURCES OF SUPPORT}




\section{Internal sources}

- No sources of support supplied

\section{External sources}

- NIHR Programme Grant, UK. Financial Support

\section{DIFFERENCES BETWEEN PROTOCOLANDREVIEW}

We changed some of the primary and secondary outcomes from those stated in the protocol:

- "Exacerbations requiring antibiotics or short burst oral corticosteroids as defined by agreed criteria" was changed to "Exacerbations; all cause, requiring short burst oral corticosteroids or antibiotics as defined by agreed criteria". We felt it was helpful to include data for the total number of exacerbations and this reflected the data reported in INSPIRE

- In addition to all cause hospital admissions, we included data for exacerbations resulting in hospital admissions to reflect the primary outcome of INSPIRE

- We added withdrawal as a secondary outcome because the high and differential withdrawal rate was important

Exacerbations, quality of life and $\mathrm{FEV}_{1}$ data were entered using generic inverse variance because the data presented in the study report required it.

\section{N DEX TERMS}

\section{Medical Subject Headings (MeSH)}

Administration, Inhalation; Adrenergic beta-Agonists [*administration \& dosage]; Albuterol [administration \& dosage; analogs \& derivatives]; Androstadienes [administration \& dosage]; Bronchodilator Agents [*administration \& dosage]; Drug Therapy, Combination [methods]; Patient Dropouts [statistics \& numerical data]; Pneumonia [drug therapy]; Pulmonary Disease, Chronic Obstructive $\left[{ }^{*}\right.$ drug therapy; mortality]; Scopolamine Derivatives [*administration $\&$ dosage]

\section{MeSH check words}

Humans 